\title{
Simulating effect of climate change on finger millet (Eleusine Coracana) yield under selected tillage practices and soil fertilizers inputs in semi-arid lower Eastern Kenya
}

\author{
Onwonga Richard ${ }^{1 *}$, Madegwa Yvonne ${ }^{1}$ and Shibairo Solomon ${ }^{2}$ \\ 1Department of Land Resource Management and Agricultural Technology, University of Nairobi, Nairobi, Kenya. \\ 2Department of Plant Science and Crop Protection, University of Nairobi, Nairobi, Kenya. \\ *Corresponding author. Email: onwongarichard@yahoo.com
}

Copyright $@ 2018$ Onwonga et al. This article remains permanently open access under the terms of the Creative Commons Attribution License 4.0, which permits unrestricted use, distribution, and reproduction in any medium, provided the original work is properly cited.

Received 14th February 2017; Accepted 20th March, 2017

\begin{abstract}
The current study, conducted in semi-arid Machakos and Kitui Counties of Kenya, simulated effect of climate change (CC) on finger millet yield under different soil fertilizer inputs (SFI), tillage practices (TP) and projected CC scenarios using the Agricultural Production Systems Simulator (APSIM) model. A randomized complete block design with split plot arrangement was employed. Main plots were TP; oxen plough-OP, ridges and furrows-RF with SFI; Farm yard manure-FYM, Triple super phosphate-TSP + Calcium Ammonium Nitrate-CAN (TSP+CAN) and no fertilizer input as splitplots. The CC scenarios considered were; Current Rainfall (R0) and Temperature (T0) provided the baseline, R1 (R0+10\% increase in rainfall), R2 (R0-10\% decrease in rainfall), $\mathrm{T} 1(\mathrm{~T} 0+20 \mathrm{C})$ and $\mathrm{T} 2$ (the combined effects of $10 \%$ decrease in rainfall and $20 \mathrm{C}$ increase in temperature $(-10 \%+20 \mathrm{C})$. Significantly $(P \leq 0.001)$ higher finger millet yields were obtained in $\mathrm{TSP}+\mathrm{CAN}$ treated plots compared to FYM and control in both Kitui (with higher yields) and Machakos. Comparatively, finger millet yields were well simulated with moderate RMSE $(1.04,0.94)$ values in OP and RF in Kitui and low values (0.18) in OP in Machakos). Simulated finger millet yields mirrored measured yields, and were higher in Kitui (RF) than Machakos (OP) with TSP+CAN recording highest simulated yields compared to FYM and control. R1 (R0+10\% rainfall) registered significantly high finger millet yields under $\mathrm{OP}$ and $\mathrm{RF}$ with application of TSP+CAN in both sites. The lowest finger millet yields, across sites were noted in T2 $\left(-10 \%\right.$ rainfall $\left.+2^{\circ} \mathrm{C}\right)$, in decreasing order; TSP+CAN; FYM and control under OP and RF. Finger millet yields measured and simulated, insitu and across CC scenarios, indicated that application of TSP+CAN under conservation tillage practices (RF in Kitui and OP in Machakos) consistently gave superior yields compared to FYM and control. In the event of change of climate favouring increased rainfall (R1), finger millet grown under $\mathrm{RF}$ and OP with application of TSP+CAN may have the potential to adapt to climate change and enhance food and nutritional security. Further studies, mainly focusing on moisture conservation and breeding of drought tolerant crops, are nonetheless recommended to generate possible CC adaptation strategies under R2, T1 and T2 possible climate change scenarios in semi-arid regions of Kenya.
\end{abstract}

Key words: APSIM, climate change scenarios, farm yard manure, indigenous crops, mineral fertilizers, modeling, oxen plough, ridges and furrows.

\section{INTRODUCTION}

Arid and semi-arid regions which make up to $80 \%$ of Kenya's landmass (MoA 2007) are characterized by low erratic rainfall, poor soil fertility (FAO, 2008), and food insecurity (GoK, 2011). Besides, these regions are most vulnerable to impacts of climate change (Madegwa et al., 2016). Lower Eastern Kenya, being a semi-arid region has not been immune to effects of climate change (Jesen et al., 2003). Agricultural production in this region has 
been on the decline in recent years due to low rainfall and soil moisture content, high temperatures and solar radiation (Bishaw et al., 2013), unsustainable tillage practices, such as conventional tillage, and increasing effects of climate change. Use of conventional tillage practices, characterized by regular ploughing of the soil, inverts the soil thereby burying surface vegetation and crop residues. Furthermore, conventional tillage systems traditionally suffer from severe soil organic matter (SOM) depletion due to intense decomposition following soil ploughing, the removal of most of the aboveground biomass during harvest, and the enhanced soil erosion inherent to those activities (Lipper et al., 2011). This in addition to soil fertility depletion (Claassen, 1996). The depletion of soil fertility can be countered by the introduction of conservational cultivation practices such as minimum tillage with appropriate soil fertilizer inputs and adoption of low fertility crops such as cowpea, millet, sorghum and cassava (Samantha, 2001 and Tolessa, 2006). Greater crop yields in conservation tillage (e.g. ridge tillage) relative to conventional tillage have been reported in Ghana (Akinyemi et al., 2003) and Kenya (Miriti et al., 2012).

Conservation practices that contribute to better natural resources management include mulching, ridging, pitting, terracing, oxen plough, integrated nutrient management and manure management options among others. These practices increase infiltration and moisture retention in the soil profile for crop growth (Fox and Rockstom, 2003; Kaumbutho and Kienzle, 2007). Miriti et al. (2012) observed that soil water was best conserved in the order tied-ridge tillage, ox-plough tillage and subsoiling ripping tillage. Tillage practices such as oxen plough and ridges and furrows are seen as possible solutions to reducing soil moisture loss (Claassen, 1996). Ridges and Furrows are particularly useful in arid and semiarid regions where irrigation water is not available or is expensive (Boers et al., 1986). This technique can improve soil moisture storage, prolong the period of moisture availability and enhance production of agricultural, horticultural and forest crops (Boers et al., 1986; Cater and Miller, 1991).

Besides conservation tillage practices, to address low soil fertility application of organic and inorganic fertilizers is critical (Lema and Degebassa, 2013) for enhanced crop productivity. Organic manures improve physical, chemical and biological conditions of the soil (Crown and Dunn, 2010), whereas mineral fertilizers have been the primary means of enhancing soil fertility in small-farm agriculture for many years (Lema and Degebassa, 2013).

Studies combining the use of conservation tillage practices, fertilizers and finger millet production in particular are, however, scanty (Madegwa et al., 2016). Cognizant of the effects of climate change on agricultural production in arid and semi-arid lands (ASALs), finger millet cultivation is being promoted as an adaptation strategy to the adverse effects of climate change (CC) and subsequently alleviation of food insecurity in ASALs
(Taylor, 2003). This is due to finger millet's inherent characteristics; high nutrient content, drought resistance, pest/disease resistance and ability to produce with little inputs (Holt, 2000), that makes it more adapted to the harsh African environment (Kotschi, 2006). However, with increasing effects of climate change, there is a dire need to evaluate the effect of various climate change scenarios on finger millet production with the aim of developing appropriate, well-grounded and informed adaptation mechanisms.

Use of crop simulation models such as the Agricultural Crop Production System Simulator (APSIM) is a reliable way to achieve this objective (Keating et al., 2003). Use of crop simulation models has been on the rise in recent years due to time and resources (Jones et al., 2003) incurred during field experimentation, especially as the number of variables and treatments increases. Climate change has further reduced popularity of field experiments as they are done against the backdrop of changing weather parameters, making it nearly impossible to create exact conditions desired for conducting experiments (Whisler et al., 1986).

The APSIM model has proved to be reliable in studies carried out in the African continent. Some of these studies include plant growth (Ahmed and Hassan, 2011) nutrient competition (Keating et al.,1999), plant nutrient uptake (Carberry, 2002), impact of climate variability on crop production (Keating et al., 2003; Tsubo et al., 2005; Wu et al., 2006 and Wang et al., 2008) among others.

The aim of this study was therefore to evaluate and simulate the effect of climate change on finger millet yields under different soil fertilizer inputs and tillage practices in semi-arid lower eastern Kenya using the Agricultural Production Systems Simulator Model.

It is envisaged that promotion of drought tolerant crops such as finger millet and switching to more moisture conserving tillage techniques could form the first steps in response to low rainfall in these areas and in the long run, help to counter the problem of declining agricultural productivity and food insecurity in the arid and semi-arid areas of Kenya.

\section{MATERIALS AND METHODS}

\section{Site description}

The study was carried out in Kalama and Katangi divisions of Machakos and Kitui Counties (Figure 1) respectively of semi-arid lower Eastern Kenya. Machakos County is located between Latitudes $0.45^{\prime} S$ to $1{ }^{\circ} 31^{\prime} S$ from north to south and Longitudes $36^{\circ} 45^{\prime} \mathrm{E}$ and $37^{\circ} 45^{\prime} \mathrm{E}$ from east to west with a mean altitude of 1714 meters above sea level. Long rainy season fall between March and May and short rainy season between October and December (Jaetzold et al., 2006). Dominant soil groups are acrisols, ferrasols and andasols (WRB, 2006). Main agricultural activities include 


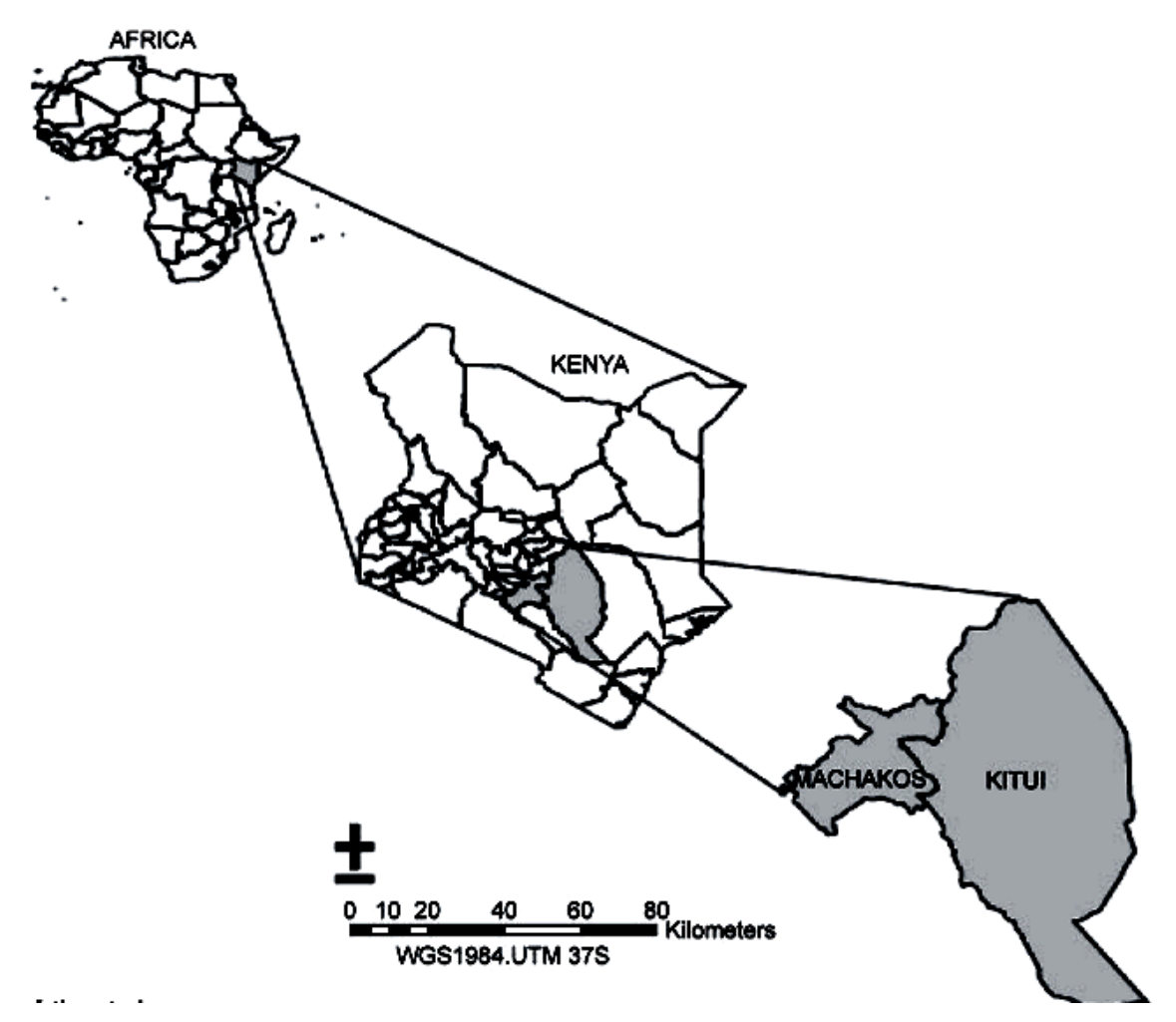

Figure 1. Map showing the location of the study sites (Wagate et al., 2010).

small scale livestock keeping, cultivation of maize, mangoes, papaws, watermelons, cow peas, beans, pigeon peas and lentils (Thiongo et al., 2016).

Kitui County is located between Latitude of $0^{\circ} 3.7^{\prime}$ and $3^{\circ} 0$ South and Longitude $37^{\circ} 45^{\prime}$ and $39^{\circ} 0^{\prime}$ ' East with an altitude of 1151 meters above mean sea level (Pauw et al., 2008). The region receives average rainfall of about 900 $\mathrm{mm}$ (van Loon and Droogers, 2006). Long rains fall between April and May, while short rain between October and December (Pauw et al., 2008). Soils in Kitui are a combination of acrisols and luvisols with ferralsols (WRB, 2006). Main agricultural activities include subsistence crop (maize, beans, cowpea, pigeon pea, cassava, cotton) and livestock (cattle, sheep and goats) farming.

Machakos and Kitui Counties regions are both prone to high temperatures (average $22.50 \mathrm{C}$ ), low and erratic rainfall (231 to $361 \mathrm{~mm}$ per annum) and highly vulnerable to climate change (Jaetzold et al., 2006).

\section{Treatment and experimental design}

On farm fields experiments were conducted within each county and run for two seasons. Experimental set up was a randomized complete block design with split plot arrangement. Main plots were two tillage practices (TP): (i) oxen plough (OP) and, (ii) ridges and furrows (RF), while split plots were soil fertilizer inputs: (i) farm yard manure
(FYM with (\%) N, P and OC of 2.75, 1.03 and 37 respectively. Carbon: Nitrogen (C: $\mathrm{N})$ ratio (13.82) and $\mathrm{pH}$ (H2O) of 8.6), (ii) Triple Super Phosphate (TSP) combined with Calcium Ammonium Nitrate (CAN) (TSP+CAN) and no fertilizer input (absolute control) was also included in the split plot.

\section{Land preparation, fertilizer application and planting}

The RF were constructed manually using a hand hoe to heap the top soil to a height of $30 \mathrm{~cm}$ for ridges and a depth of $15 \mathrm{~cm}$ for furrows. OP tillage was established using a normal oxen plough at a depth of $15 \mathrm{~cm}$ (from soil surface - plough layer). FYM (10t/ha) and TSP (45kg/ha) was applied by hand during planting. CAN $(40 \mathrm{~kg} / \mathrm{ha})$ was top dressed three weeks after planting. Planting of finger millet was done at a spacing of $30 \mathrm{~cm}$ by $15 \mathrm{~cm}$ and at a depth of $0.5 \mathrm{~cm}$ (Oduori 2008). Weeding was done by hand every three to four weeks after planting.

\section{Soil sampling and analysis}

Soil sampling was done before planting and harvesting. Initial soil samples were collected in a zigzag manner across the entire field at depth of 0 to $30 \mathrm{~cm}, 30$ to $60 \mathrm{~cm}$, 60 to $90 \mathrm{~cm}$. Thereafter, samples for chemical analysis $(\mathrm{N}$, 
Table 1. Soil parameters measured and associated analytical methods.

\begin{tabular}{|c|c|c|}
\hline Soil parameters & Analytical methods & Reference \\
\hline Bulk Density (g/cm3) & $\begin{array}{l}\text { Samples weighed and oven dried (1050C) to } \\
\text { constant weight and bulk density determined based } \\
\text { on the oven dry weight of soil per unit volume. }\end{array}$ & $\begin{array}{l}\text { Blake and Hartge } \\
(1986)\end{array}$ \\
\hline $\begin{array}{l}\text { Saturated water content } \\
\text { (cm3/cm3), Drained } \\
\text { Upper Limit }(\mathrm{cm} 3 / \mathrm{cm} 3) \\
\text { Lower limit }(\mathrm{cm} 3 / \mathrm{cm} 3)\end{array}$ & $\begin{array}{l}\text { Pressure plate method- Where the soil sample is } \\
\text { brought to a specific water potential by applying } \\
\text { pressure at different heads, and allowing excess } \\
\text { water to flow out. Once soil samples reach required } \\
\text { water potential under pressure, the water content is } \\
\text { determined for each head. }\end{array}$ & (Richards, 1948) \\
\hline Organic C (g/kg) & $\begin{array}{l}\text { Walkley black method in which } 10 \mathrm{ml} \text { of soil sample is } \\
\text { digested with potassium dichromate and } \\
\text { concentrated sulphuric acid. The solution is then } \\
\text { titrated with ammonium ferrous sulphate with di } \\
\text { phenylamine as an indicator. }\end{array}$ & $\begin{array}{l}\text { Nelson and Sommers } \\
(1982)\end{array}$ \\
\hline Total N (\%) & $\begin{array}{l}\text { Kjeldahl procedure which involves using sulphuric } \\
\text { acid to decompose organic substances and oxidize } \\
\text { organic nitrogen as ammonium sulphate for nitrogen } \\
\text { extraction. }\end{array}$ & $\begin{array}{l}\text { Bremner and Mulvaney } \\
\text { (1982) }\end{array}$ \\
\hline$P(\mathrm{mg} / \mathrm{kg})$ & $\begin{array}{l}\text { Olsen method where } \mathrm{P} \text { is extracted using Olsens } \\
\text { extracting solution }(\mathrm{NaHCO}) \text { at } \mathrm{pH} 8.5\end{array}$ & $\begin{array}{l}\text { Olsen and Sommers } \\
(1982)\end{array}$ \\
\hline $\mathrm{pH}$ & $\begin{array}{l}\text { Mixing soil sample and } \mathrm{KCl} \text { at a ratio of } 1: 2.5 \text { soil to } \\
\mathrm{KCl}(1 \mathrm{M}) \text {, and using standardized } \mathrm{pH} \text { meter and } \\
\text { glass electrodes to determine } \mathrm{pH}\end{array}$ & Okalebo (2002) \\
\hline CEC & $\begin{array}{l}\text { Mehlich procedure which involves extracting the } \\
\text { cations using mehlich solution and determining } \\
\text { concentrations using Atomic absorption } \\
\text { spectrophotometry (AAS) }\end{array}$ & $\begin{array}{l}\text { Nelson and Sommers } \\
(1982)\end{array}$ \\
\hline $\mathrm{Na}, \mathrm{K}$ and $\mathrm{Ca}$ & $\begin{array}{l}\text { Ammonium acetate method which involves extraction } \\
\text { of nutrient from the soil through leaching with } 1 \mathrm{~N} \\
\text { ammonium acetate }\end{array}$ & McLean et al, (1959) \\
\hline Texture & $\begin{array}{l}\text { Soil texture classes and size classification according } \\
\text { to USDA system }\end{array}$ & $\begin{array}{l}\text { Gee and Bauder } \\
(1986)\end{array}$ \\
\hline
\end{tabular}

$\mathrm{P}, \mathrm{K}, \mathrm{OC}, \mathrm{Na}, \mathrm{Ca}, \mathrm{pH}, \mathrm{CEC})$ were collected from each plot and thoroughly mixed to make composite soil samples. Samples for soil Physical analysis (Texture, Bulk density) were collected using core rings. Soil analysis was performed using standard analytical procedures (Table 1) as compiled and described by Okalebo et al. (2002) and Estefan et al. (2013).

\section{Plant sampling, biomass and yield determination}

Plant samples for determination of dry matter and grain yields were collected from the inner rows in each plot in a $1 \mathrm{~m}^{2}$ quadrant. After determining the weight of 14 to 18 plants, six plants corresponding to average weight were selected and their dry matter was determined after ovendrying at $80^{\circ} \mathrm{C}$ to a constant weight for 72 hours. Samples were then weighed using a digital weighing scale and weight recorded. The dry matter weight was then extrapolated to $\mathrm{kg} / \mathrm{ha}$. The finger millet fingers were threshed and winnowed to remove grain and after which grain yields were determined by weighing the grains obtained from the $1 \mathrm{~m}^{2}$ quadrant and converted into t/ha.

\section{APSIM data requirements, calibration and validation}

\section{Data requirements for APSIM modelling}

APSIM (version 7.3) was configured to simulate finger millet yields under different tillage practices and soil 


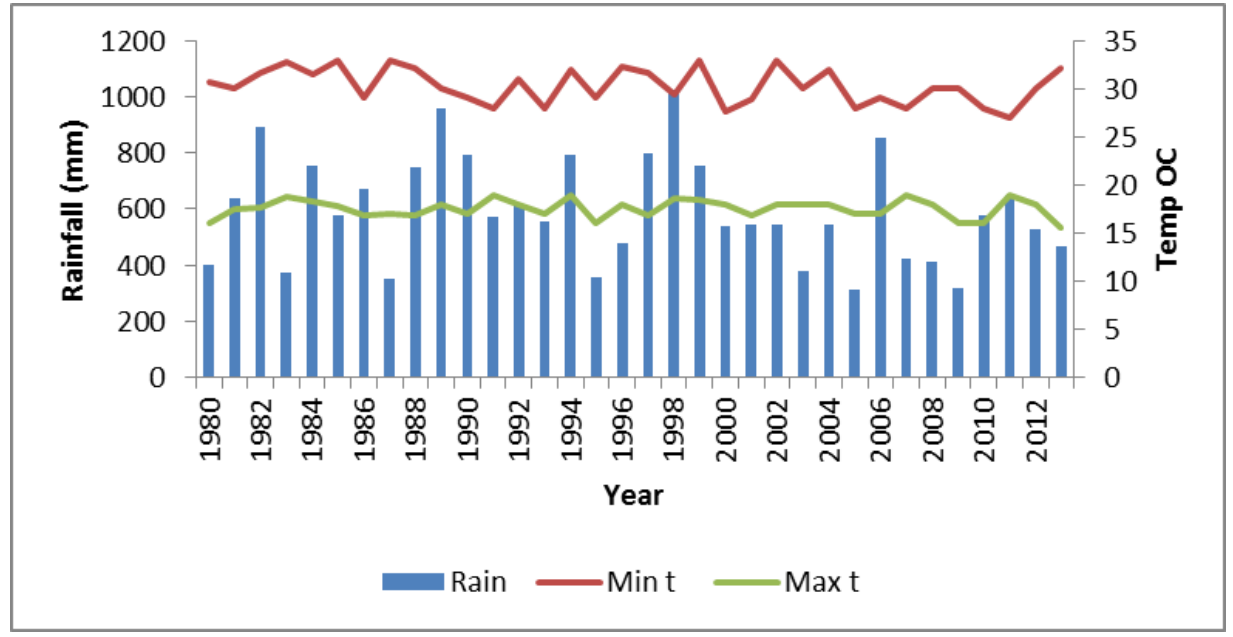

Figure 2. Average annual rainfall, maximum and minimum temperature trend in Kitui.

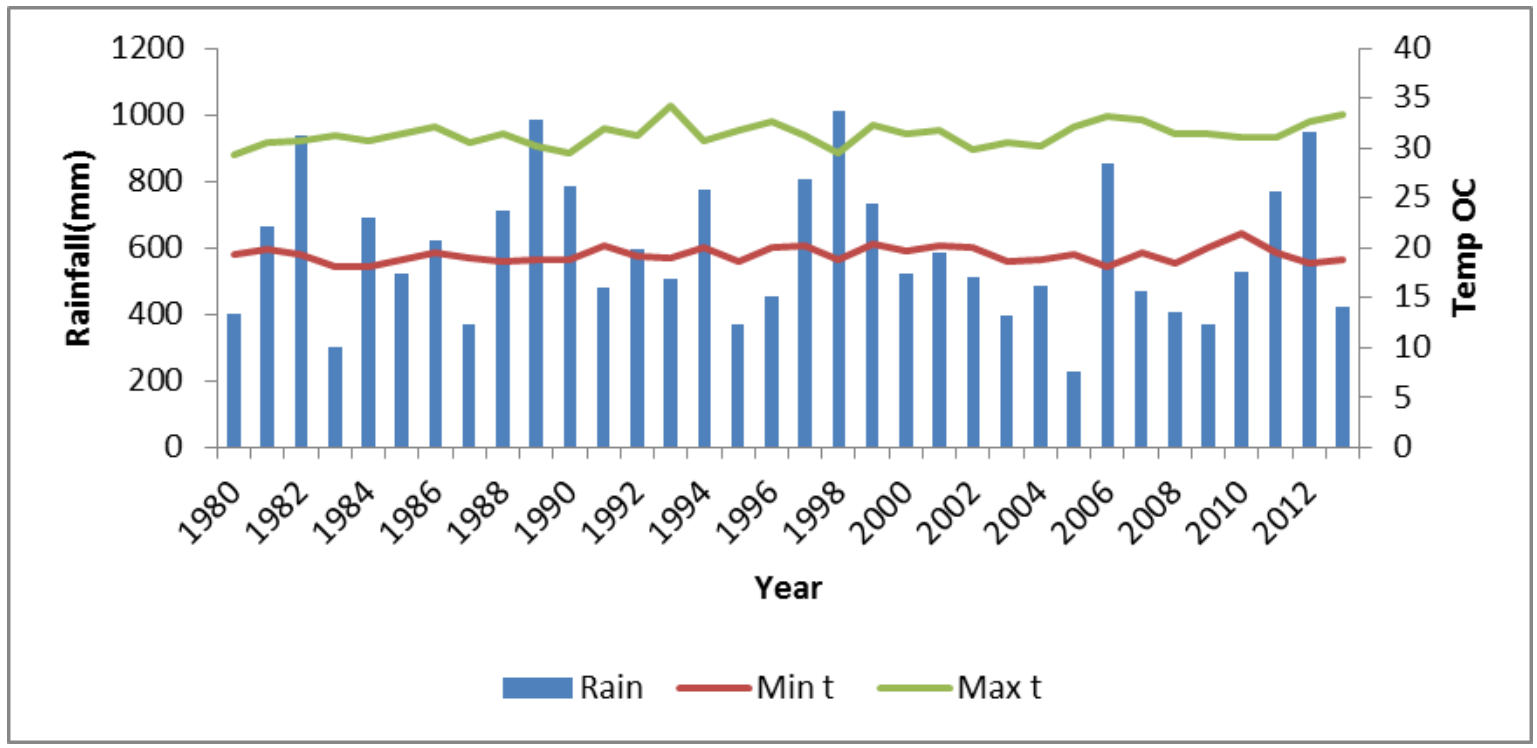

Figure 3. Average annual rainfall, maximum and minimum temperature trend in Machakos.

fertilizer inputs during the 2013 short and long rain seasons. The data (Probert et al., 1998) required for model parametrization included:

Meteorological data: The meteorological data used included; daily data on rainfall, radiation, maximum temperature (Max t) and minimum temperature (Min t) (Figures 2 and 3 and Tables 2 and 3 ). These data were obtained from nearest weather sub-stations in Kalama (Machakos) and Katangi (Kitui) for a period of 33 years (That is, from 1980 to 2013).

Soil Data: APSIM requires several soil parameters (Table 1, Probert et al. (1998) and www.apsim.info). A soil profile was dug and sampled for estimates of drained upper limit
(DUL, $\mathrm{mm} \mathrm{mm}^{-1}$ ), and drained lower limit (LL15, $\mathrm{mm} \mathrm{mm}^{-}$ $\left.{ }^{1}\right)$, bulk density $\left(\mathrm{BD}, \mathrm{g} \mathrm{cm}^{-3}\right)$, soil $\mathrm{pH}$, organic matter (OM, $\%$ ), clay content, Saturated water content (SAT, $\mathrm{mm} \mathrm{mm}^{-}$ 1) was calculated from bulk density as described by Dalgliesh and Foale (2005).

The soil moisture limit to which soil can dry by evaporation (Airdry, $\mathrm{mm} \mathrm{mm}^{-1}$ ) was estimated as $0.5 \times$ LL15 in 0 to $15 \mathrm{~cm}$ soil layer, $0.9 \times$ LL15 in 15 to $30 \mathrm{~cm}$ soil layer and equal to LL15 at deeper depths (Cresswell et al., 2009). For unsaturated water flow the default values for APSIM coefficients (diffus_const and diffuse_slope) were used. Organic carbon $(\mathrm{O} \overline{\mathrm{C}}, \%)$ was estimated from $\mathrm{OM}$ (OC = OM/1.72; Dalgliesh and Foale, 2005). The APSIM default value coefficients (Probert et al., 1998) were used to partition OC to different pools (BIOM, HUM, and INERT). 
Table 2. Monthly rainfall, mean monthly maximum and minimum temperature in Kitui during the experimental period.

\begin{tabular}{lcccccccccccc}
\hline Parameters & Jan & Feb & Mar & Apr & May & Jun & Jul & Aug & Sep & Oct & Nov & Dec \\
\hline Rain (mm) & 9.5 & 38.5 & 116.3 & 120.3 & 4.0 & 0.0 & 0.0 & 1.0 & 1.0 & 20.1 & 150.3 & 6.5 \\
Max Temp (OC) & 30.0 & 30.5 & 32.4 & 23.2 & 28.3 & 28.2 & 23.7 & 26.6 & 30.5 & 33.1 & 27.5 & 30.1 \\
Min Temp (OC) & 16.0 & 17.7 & 18.2 & 20.1 & 17.1 & 18.0 & 15.7 & 15.4 & 15.2 & 18.6 & 19.7 & 20.9 \\
\hline
\end{tabular}

Source: Katangi weather sub-station, Kitui.

Table 3. Monthly rainfall, mean monthly maximum and minimum temperature in Machakos during the experimental period.

\begin{tabular}{lcccccccccccc}
\hline Parameters & Jan & Feb & Mar & Apr & May & Jun & Jul & Aug & Sep & Oct & Nov & Dec \\
\hline Rain (mm) & 5.4 & 37.2 & 115.4 & 65.3 & 10.1 & 1.0 & 0.0 & 1.0 & 1.5 & 32.7 & 140.7 & 5.1 \\
Max Temp (0C) & 32.2 & 33.3 & 31.2 & 29.6 & 30.7 & 28.1 & 27.8 & 26.9 & 29.0 & 32.7 & 26.1 & 29.3 \\
Min Temp (OC) & 20.7 & 20.8 & 21.6 & 21.7 & 19.7 & 20.5 & 18.3 & 18.3 & 19.8 & 20.5 & 19.3 & 21.2 \\
\hline
\end{tabular}

Source: Kalama sub-weather station, Machakos.

Crop data: Crop data was collected through field observations and registry of crop phenology stages; sowing (sowing date, sowing rate), germination (emergence, flowering harvesting dates) and crop management: crop (crop type and variety), seeding (plant spacing) and organic inputs (date of application, amount and nutrient content).

\section{APSIM model calibration}

As APSIM is not calibrated for finger millet, the "pearl millet" module was used as a proxy and adjustments made towards finger millet crop. Pearl Millet was chosen due to similar characteristics alluded to all millets that make them closely related functionally, ecologically and agronomicaly (Obilana, 2003).

A new simulation was created in APSIM and calibrated to simulate finger millet yields as affected by tillage practices (OP, RF) and soil fertilizer inputs (FYM, $\mathrm{TSP}+\mathrm{CAN}$ and control - no fertilizer input). The first module used to build the simulation was 'Met module' which incorporates all weather variables (daily rainfall, maximum temperature, minimum temperature, solar radiation from 1980 to 2013) into the model. Also included in the met file were full descriptions of location, latitude and annual average temperature. The "Clock" module was used to input start (1/1/2013) and end dates $(31 / 12 / 2013)$ for the simulation. The "summary file" which displayed all information about the run, including settings, problems encountered, management options carried out and errors was also included in the simulation. The "Paddock module" which is the main module that includes all information about the crop, soil management-including planting and harvesting, and an output file (which summarizes all simulation outputs) were also included in the simulation.
Under this module, the following folders were incorporated into the simulation: Soil Wat (Soil water), Surface om (Surface organic matter), Soil N (Soil Nitrogen), Soil P (Soil phosphorous), manure and Fertilizer, (in order to incorporate soil physical and chemical characteristics). Using the APSIM-millet module, for APSIM calibration, data collected through field observations and registry of crop phenology stages; sowing (sowing date, sowing rate), germination (emergence, flowering harvesting dates) and crop management: crop (crop type and variety), seeding (Plant spacing) were incorporated into the simulation.

To capture the effect of various soil fertilizer inputs, the "apply manure on a fixed date" and "apply fertilizer on a fixed date" including date of application, amount and nutrient content were incorporated into the simulation. To capture effect of tillage practices curve number was set at 5 and 10 for oxen plough and ridges and furrows respectively (Stephen Kimani, Personal Communication) based on the assumption that oxen plough had a higher runoff potential than ridges and furrows. Simulations were run under nutrient non limiting conditions, with no pest occurrences or weed infestation. Growth and yield data collected were further used as input parameters to calibrate the millet module. With the requisite data for APSIM simulation set, the model was run and predicted finger millet yields were compared with measured values.

\section{APSIM model validation}

The calibrated model was then validated using field experimental data (yields). The validation process was aimed at determining model sensitivity and performance by comparing observed and simulated yields using the following statistical formulae; Root mean square error (RMSE), Correlation coefficient ( $r$ ), Coefficient of determi- 
nation (r2) and Range ratio (RR). Root mean square error (RMSE) is considered a good measure of model performance as it provides information on overall model performance (Willmott and Matsuura, 2005) with low values are an indication of good model performance (Smith et al. 1996). The determination of how low, middle or high the values are determined by the range of the dataset.

$\operatorname{RMSE}=\sqrt{\left[\mathrm{n}^{-1} \sum\left(\mathrm{p}_{1-} \mathrm{O}_{\mathrm{i}}\right)\right] 2}$

Correlation coefficient $(r)$ is used to determine relationship between observed and simulated yields. Values range between -1 and 1 with higher values indicating a stronger relationship between observed and simulated values (Moore and McCabe, 1993)

Coefficient of determination (Correlation coefficient-R2) is the strength of linear association between observed and simulated values representing the proportion of unexplained variation to total variation. It's used to analyze linear relationship with higher values indicating a close relationship between measured and simulated yields.

$\mathrm{R}^{2}=\frac{\mathrm{SSR}}{\mathrm{SST}}=1-\frac{\mathrm{SSE}}{\mathrm{SST}}$

Where SSR is the regression sum of squares, SST is the total sum of squared deviations of the predicted values around their mean, and SSE is the sum of squared differences between the residuals/errors and their means. For a perfect regression, SSR $=\mathrm{SST}$ and $\mathrm{SSE}=0$, so that $\mathrm{R} 2=1$.

Range ratio (RR) compares the range of outputs between observed and simulated values focusing on extreme values between the two data sets.

$\mathrm{RR}=100 *\left\lfloor\frac{\text { Max }_{\text {observed }}-\text { Max }_{\text {observed }}}{\text { Max }_{\text {simulated }}-\text { Max }_{\text {observed }}}\right\rfloor$

\section{Climate change scenarios used in finger millet yield simulations}

The climate change scenarios used in finger millet yield simulations under the imposed treatments were based on projected rainfall and temperature expected in the study region for the 21st century under representative concentration pathway 2.6, low emission scenario (IPCC, 2007). Rainfall projections ranged from $-20 \%$ to $10 \%$ for the study region based on the Canadian Centre for Climate Modelling and Analysis (Flato et al., 2000; Flato and Boer, 2001). For finger millet yield simulations, the following climate change scenarios were considered; current Rainfall (R0) and Temperature (T0) provided the baseline, $\mathrm{R} 1(\mathrm{R} 0+10 \%$ increase in rainfall), $\mathrm{R} 2$ ( $\mathrm{R} 0-10 \%$ decrease in rainfall), T1 $(\mathrm{TO}+20 \mathrm{C})$ and T2 (the combined effects of $10 \%$ decrease in rainfall and $20 \mathrm{C}$ increase in temperature
$(-10 \%+20 C)$.

To incorporate the effect of climate change into the simulations, the "Climate control" module was used. The module was selected from the "Meteorological folder" in the Standard tool box and placed in the manager folder. The climate control module allowed changes in temperature and rainfall (as a percentage) to be effected in the simulations, and subsequent effects of the change reflected in crop yields.

\section{RESULTS AND DISCUSSION}

\section{Effect of tillage practice and soil fertilizer inputs on measured and simulated finger millet yields (Measured finger millet yields)}

Kitui had significantly $(P \leq 0.05)$ higher finger millet yields than Machakos across all TP and soil fertilizer inputs (Figure 4). This may have been caused by the high rainfall experienced in Kitui during the 2013 short and long rain season (Table 2). Xu et al. (2011) and Ngeve (2003) found that rainfall intensity and distribution was one of the main determinants of soil moisture content, which would have a direct influence on crop yields. In addition, Kitui soils had higher nutrient content than Machakos (Table 4).

The generally higher nutrient content of farms in Kitui may also be attributed to their higher clay and organic matter (Table 4) content which reduced nutrient losses through soil erosion. Morris, (2006) and Magdoff and Weil (2004) while working on the significance of soil organic matter to soil quality and health, reported that higher soil clay content reduced loss of nutrients through erosion. High organic matter content of soils in Kitui (Table 4) may have improved crop yields due to enhanced water and nutrients supply (through mineralization) as well as improved soil physical and chemical conditions. Adeyemo and Agele (2010) had also found that organic matter improved soil quality, health, and enhanced nutrient use.

In Machakos, TSP+CAN treated plots had highest (1.77 $\mathrm{t} / \mathrm{ha}, 0.86 \mathrm{t} / \mathrm{ha})$ finger millet yields compared to $\mathrm{FYM}$ (1.69t/ha, $0.78 \mathrm{t} / \mathrm{ha}$ ) and control (1.5 t/ha, $0.69 \mathrm{t} / \mathrm{ha})$ in OP and RF (Table 5).

In Kitui, TSP+CAN (1.83 t/ha, $2.11 \mathrm{t} / \mathrm{ha})$ treated plots correspondingly recorded highest yields compared to FYM (1.79 t/ha, $1.85 \mathrm{t} / \mathrm{ha})$ and control (1.72 t/ha, $1.77 \mathrm{t} / \mathrm{ha})$ in OP and RF (Table 6).

High finger millet yields in RF in Kitui may have been caused by improved soil moisture availability to plants brought about by retention of soil moisture and controlled nutrient loss through erosion with subsequent improvement of crop yields. Jia et al. (2006) and Uloro and Gebrekidan (2002) found that construction of RF reduced moisture loss and subsequently improved crop yields. Further, the improved surface roughness in RF than OP may have contributed to the observed high finger millet yields leading to improved water storage. Miriti et al. (2013) had also reported in a similar study that RF tended to have 


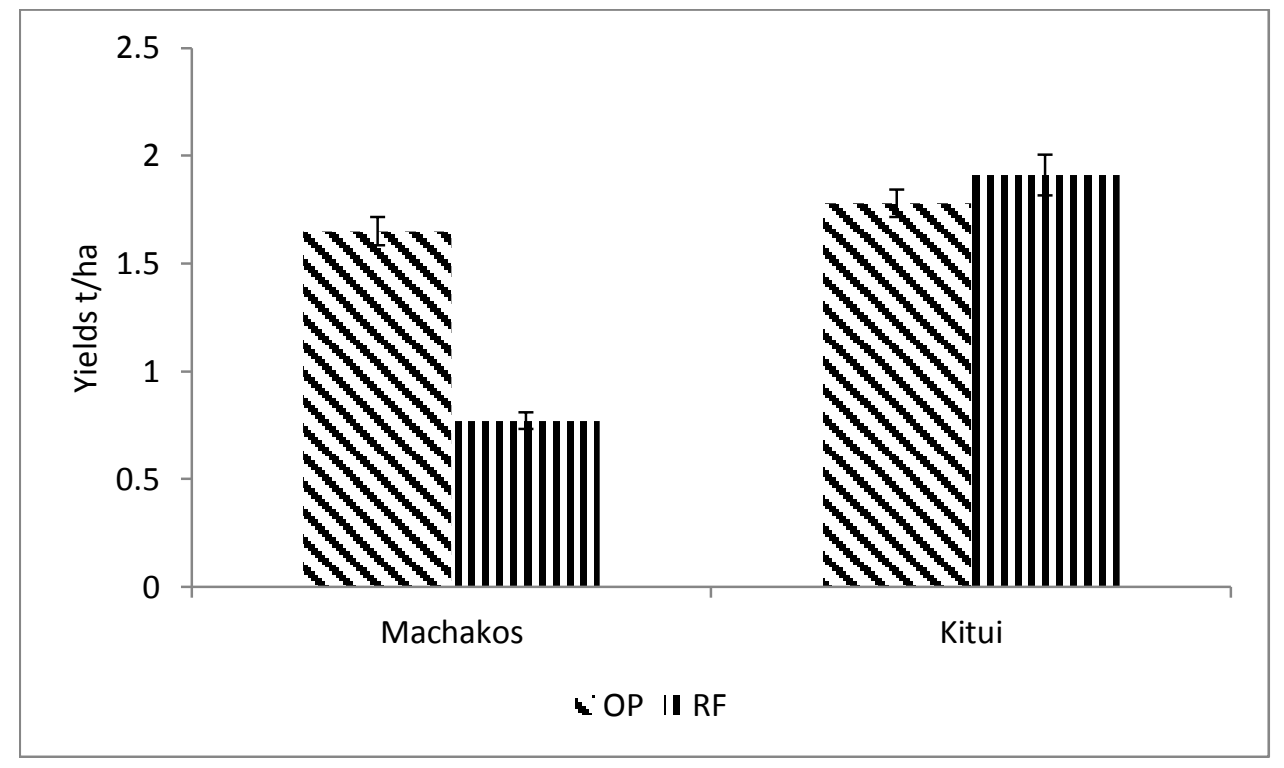

Figure 4. Effect of site (Machakos, Kitui) on finger millet yields.

Table 4. Soil profile data for Machakos and Kitui used in model calibration.

\begin{tabular}{lcccccc}
\hline Soil Parameters & \multicolumn{3}{c}{ Mach kos } & \multicolumn{3}{c}{ Kitui } \\
\hline Soil horizon depth (cm) & $0-30$ & $30-90$ & $90-150$ & $0-30$ & $30-90$ & $90-150$ \\
Saturated water content (\%vol) & 0.32 & 0.34 & 0.33 & 0.4 & 0.38 & 0.36 \\
Drained upper limit (\%vol) & 0.28 & 0.28 & 0.28 & 0.32 & 0.25 & 0.27 \\
Lower limit (\% vol) & 0.15 & 0.15 & 0.17 & 0.18 & 0.17 & 0.16 \\
Sand & 50 & 45 & 43 & 40.35 & 48.33 & 39.85 \\
Silt & 18 & 16 & 15 & 17.84 & 16.97 & 17.05 \\
Clay & 32 & 29 & 29 & 43.67 & 38.85 & 43.01 \\
Bulk density (g/cm3) & 1.28 & 1.34 & 1.31 & 1.35 & 1.32 & 1.36 \\
Organic carbon-OC (\%) & 1.21 & 1.28 & 0.46 & 1.28 & 1.34 & 0.69 \\
Total Phosphorous-P (ppm) & 25.25 & 21.48 & 16.2 & 29.45 & 24.72 & 24.3 \\
Total Nitrogen-N (\%) & 0.1 & 0.06 & 0.08 & 0.15 & 0.09 & 0.06 \\
pH (H2O) & 6.3 & 6.1 & 6.5 & 6.55 & 6.3 & 5.92 \\
Cation exchange capacity (cmol/kg) & 5.9 & 5.7 & 6.4 & 12 & 11.05 & 9.26 \\
Sodium-Na(cmol/kg) & 1.12 & 1.88 & 1.88 & 1.14 & 1.77 & 1.77 \\
Calcium-Ca(cmol/kg) & 3.12 & 3.24 & 1.41 & 3.15 & 3.27 & 1.48 \\
Potassium-K (cmol/kg) & 1.25 & 1.55 & 1.25 & 1.63 & 1.45 & 1.19 \\
\hline
\end{tabular}

a higher surface roughness than $\mathrm{OP}$, which in turn increased soil water infiltration and storage, and subsequently enhanced crop yields. This assertion is also in line with that of Hansen et al. (1999) who found that soils with higher surface roughness had higher soil moisture conservation ability than soils with lower surface roughness. The OP plots having lower yields in Kitui may have been caused by increased water and nutrient losses through erosion, as was evident from the observed formation of ox rills. According to Kaumbutho and Simalenga (1999), use of OP increased rates of moisture loss due to formation of ox rills that reduced water retention. Relatively low finger millet yields under RF in Machakos may have been caused by destruction of RF during the rainy season due to the farms high sand content (Table 4).

Soil fertilizer inputs had a significant $(P<0.05)$ effect on finger millet yields with TSP+CAN having highest yields compared to manure and control (Figure 5). This was attributable to the fact that the fertilizers (TSP+CAN) provided readily available phosphorous and nitrogen whose availability increased finger millet yields, as the two nutrients are considered the most limiting in finger millet production (Oduori 2008). According to Okalebo et al. 
Table 5. Model evaluation, observed and simulated yields in Mwala, Machakos.

\begin{tabular}{lcccc}
\hline \multirow{2}{*}{ Treatments } & \multicolumn{4}{c}{ Tillage } \\
\cline { 2 - 5 } & \multicolumn{2}{c}{ Oxen plough } & Ridges and Furrows \\
\cline { 2 - 5 } & Observed & Simulated & Observed & Simulated \\
\hline Control & 1.5 & 1.61 & 0.69 & 1.76 \\
Manure & 1.69 & 1.77 & 0.78 & 1.83 \\
Fertilizer & 1.77 & 1.9 & 0.86 & 1.95 \\
R & & & & \\
RMSE & 0.67 & & 0.53 & \\
R2 & 0.18 & & 3.62 & \\
RR & 0.5 & & 0.29 & \\
\hline
\end{tabular}

Table 6. Model evaluation, observed and simulated yields in Katangi, Kitui.

\begin{tabular}{lcccc}
\hline \multirow{2}{*}{ Treatments } & \multicolumn{4}{c}{ Tillage } \\
\cline { 2 - 5 } & \multicolumn{2}{c}{ Oxen plough } & \multicolumn{2}{c}{ Ridges and Furrows } \\
\cline { 2 - 5 } & Observed & Simulated & Observed & Simulated \\
\hline Control & 1.72 & 1.82 & 1.77 & 1.84 \\
Manure & 1.79 & 1.89 & 1.85 & 1.93 \\
Fertilizer & 1.83 & 2.3 & 2.11 & 2.6 \\
R & & & & \\
RMSE & 0.63 & & 0.65 & \\
ME & 1.04 & & 0.94 & \\
R2 & 0.31 & & 0.27 & \\
RR & 0.43 & & 0.40 & \\
\hline
\end{tabular}

(1990), use of nitrogen and phosphorous fertilizers causes a substantial increase in finger millet yields. The FYM applied plots had higher yields than control plots and this may have been as a result of addition of nutrients through application of FYM containing; (\%) N, P and OC of 2.75, 1.03 and 37 respectively. Further, manure has been found to cause increased response of plants towards better uptake of macro and micro elements and enable roots to exploit a large volume of nutrients from the soil (Yedidia et al., 2001; Altomore et al., 1999). The relatively low finger millet yields with application of FYM compared to TSP+CAN can be attributed to the applied manure's low phosphorous content compared to that of TSP. This observation has also been made by Mugunda and Tenywa (1999) who found that treatments with phosphorous fertilizer performed better than those with FYM and attributed this behavior to manures' lower phosphorous content.

\section{Model calibration, simulated and measured finger millet yields}

\section{Model calibration}

The calibration process aimed at analyzing the differences between observed and simulated parameters, in order to evaluate model performance.

Comparative analysis of finger millet yields showed nonsignificant yield differences between measured and simulated yields under OP for Machakos with a moderate correlation value of 0.50 (Figure 6). In Machakos RF, there was a significant difference $(P \leq 0.05)$ between observed and simulated yields with a poor correlation value of 0.29 (Figure 6).

The large difference between observed and simulated yields under ridges and furrows may have been caused by environmental effects in the field that could not be simulated by the model. One such factor was high sand content of ridges and furrows plots that caused destruction of ridges during rainy season, and rendered them ineffective. Jewell (1995) reported that ridges and furrows on soils with a high sand content were easily destroyed by rainfall. The differences between measured and observed finger millet yields may partly be attributed to the fact that pearl millet was used as a proxy to finger millet and may have therefore be a pointer to crop physiological differences. According to Reilly (2002), the use of proxy crops has many limitations; without actually simulating the omitted crops. One cannot easily establish the error involved in using one crop or another as a proxy. 


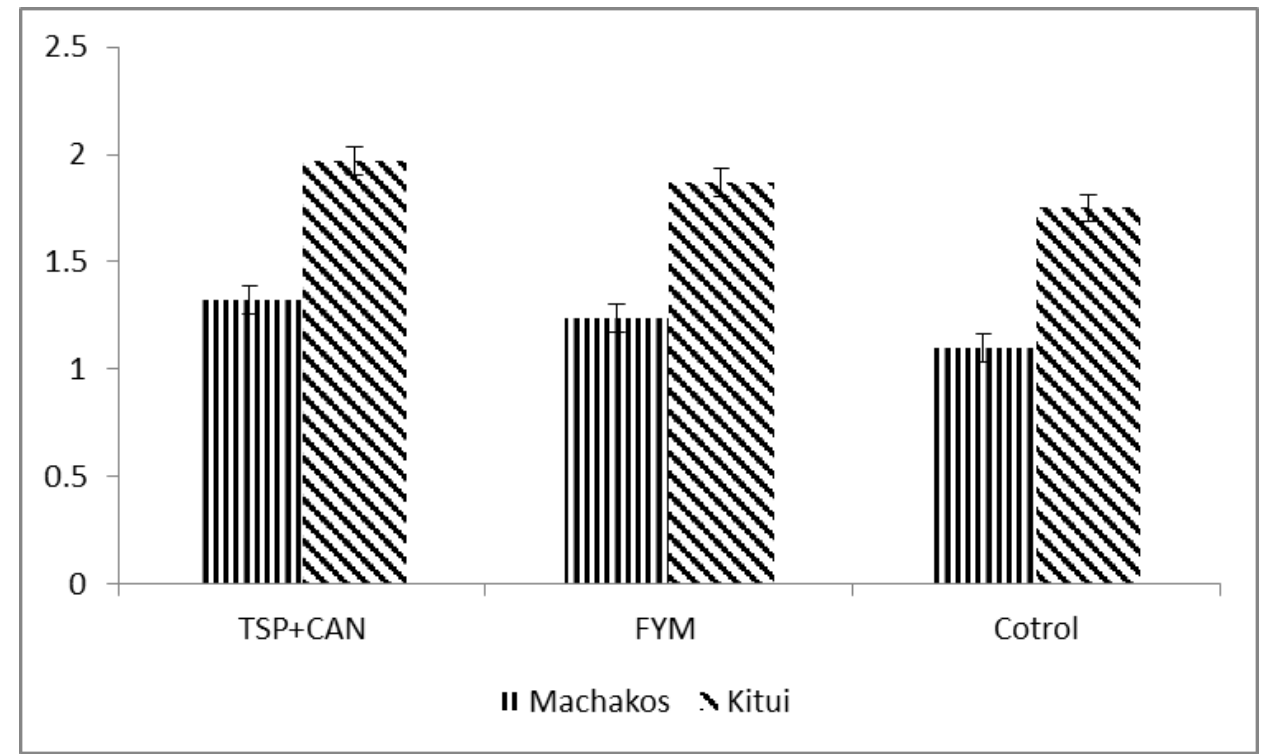

Figure 5. Effect of soil inputs on finger millet yield.
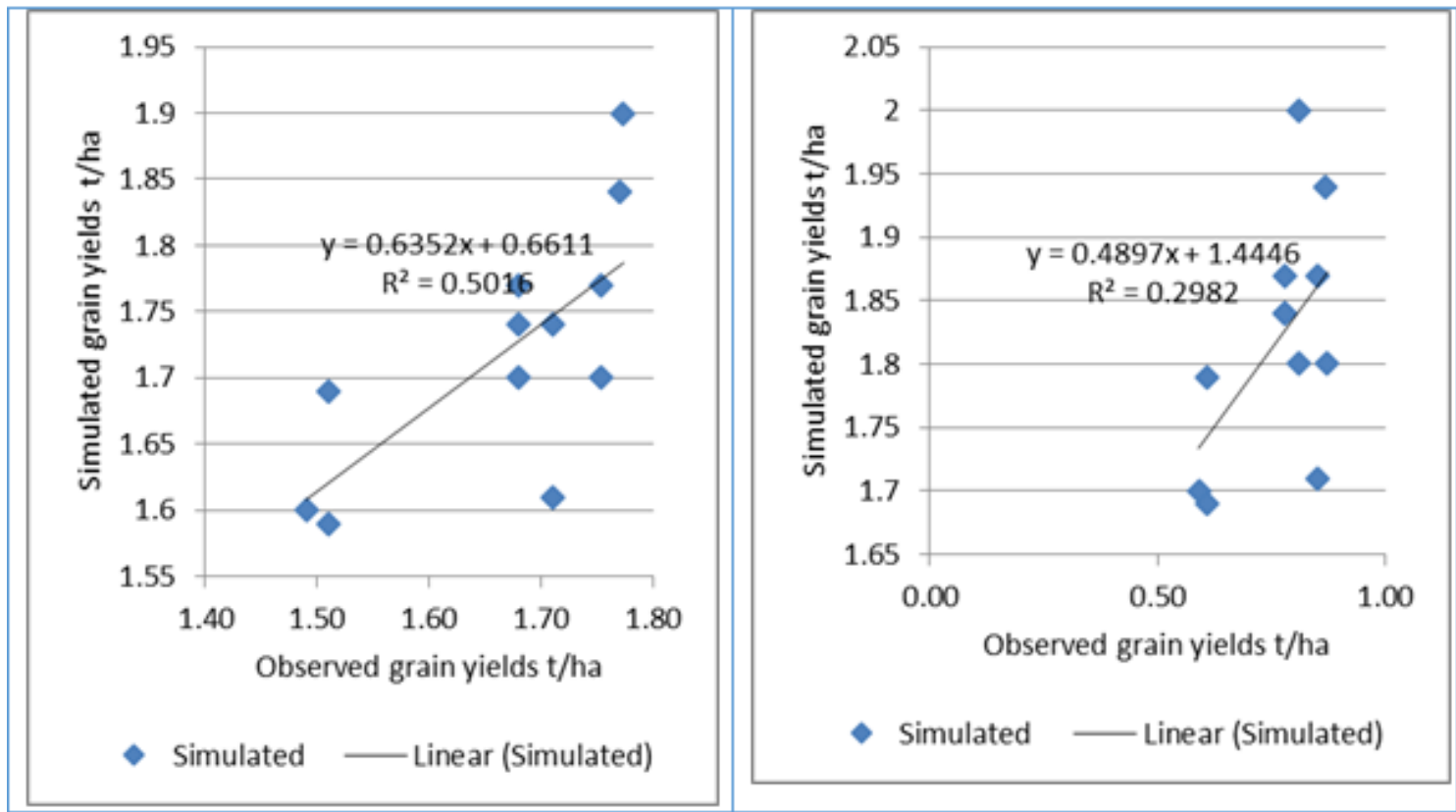

Figure 6. Observed and simulated millet yields for Machakos OP and RF, respectively.

In Machakos, grain yield predictions in response to tillage practices and fertilizers were well predicted for OP with correlation coefficient values close to one (0.67) and low RMSE (0.18) indicating a close relationship between observed and simulated values (Table 5). However, for Machakos RF, the high RMSE values (3.62) and high range ratio $(74 \%)$ showed a tendency of model over prediction (Table 5).

In Kitui, the difference between measured and simulated finger millet yields were significantly $(P \leq 0.05)$ different with $R$ values of 0.43 and 0.40 for $O P$ and RF respectively showing tendency towards model over prediction (Figure 7). The strength of linear relations between observed and simulated values was moderate for both regions with correlation values closer to 0.5 than 1 .

In Kitui, grain yields in response to tillage practices and fertilizers were well predicted with correlation coefficient values of $(0.63,0.65)$ and RMSE values of $(0.94,1.04)$ 

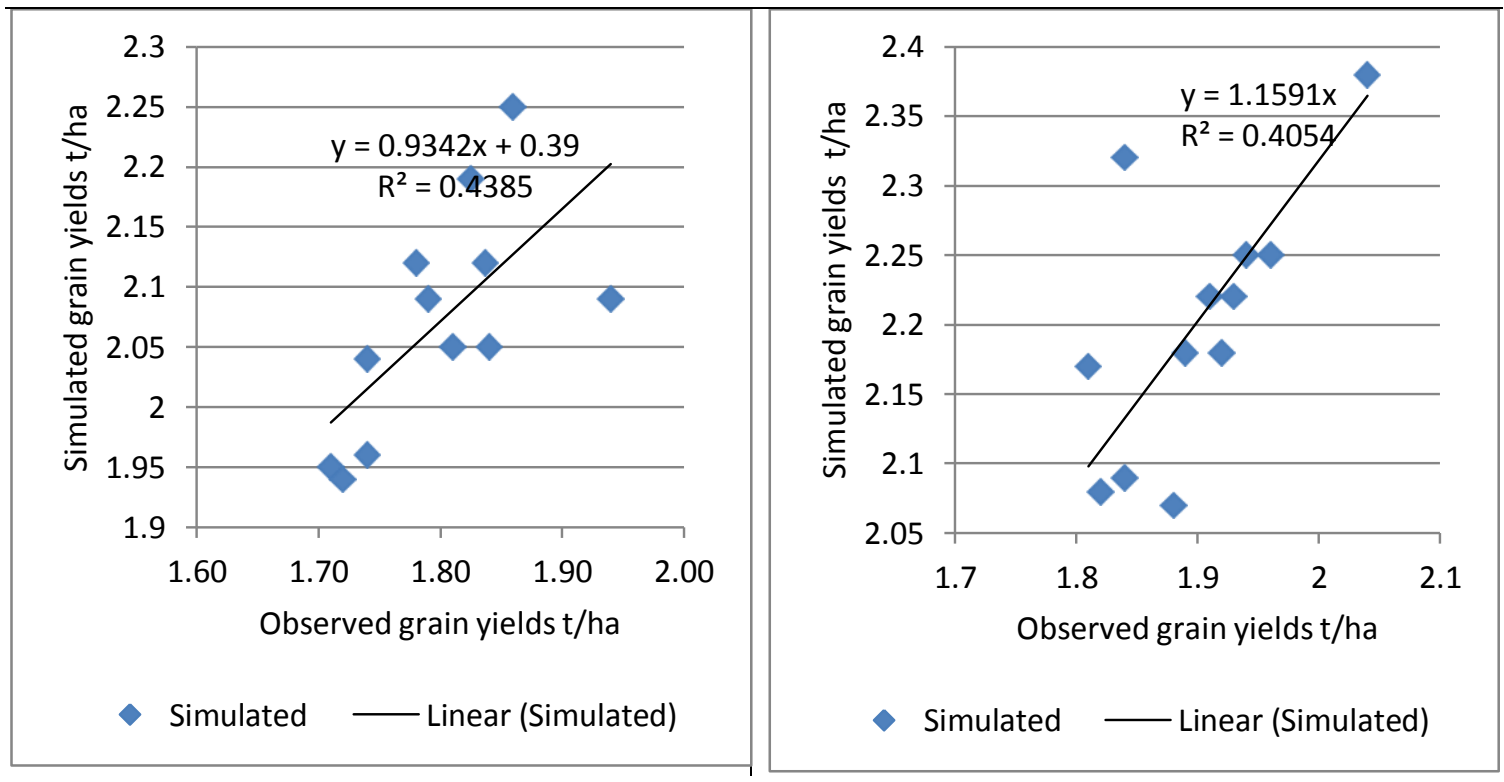

Figure 7. Observed and simulated millet yields for Kitui OP and RF respectively.

indicating a moderate relationship between observed and simulated values (Table 6) in OP and RF respectively. Simulated means were better predictors than observed means as shown by RR values of 40.35 and 42.59 in OP and $R F$ respectively.

\section{Simulated and measured finger millet yields}

Simulated finger millet yields varied across sites with Kitui registering high finger millet yields than Machakos. In Kitui, TSP+CAN (2.3 t/ha, $2.6 \mathrm{t} / \mathrm{ha})$ treated plots recorded highest simulated yields compared to FYM (1.89 t/ha, 1.93 $\mathrm{t} / \mathrm{ha}$ ) and control (1.82 t/ha, 1.84t/ha) in OP and RF in that order. Simulated yields in Kitui were $16 \%$ higher than observed yields in both RF and OP plots (Figure 8).

In Machakos TSP+CAN (1.9 t/ha, $1.95 \mathrm{t} / \mathrm{ha}$ ) treated plots had highest simulated yields compared to FYM (1.77 t/ha, $1.83 \mathrm{t} / \mathrm{ha}$ ) and control (1.61 t/ha, $1.76 \mathrm{t} / \mathrm{ha}$ ) in OP and RF respectively. In Machakos, differences between observed and simulated finger millet yields were higher in RF plots (138\% higher) than OP plots (16\% higher) (Figure 9 ).

In Machakos however, RF had higher simulated finger millet yields than OP, unlike field experiments where OP performed better than RF (Table 5). Model over prediction of finger millet performance for RF may be attributed to the farms' high sand content (Table 4) which contributed towards destruction of the RF structures, rendering them ineffective. Simulated yields being higher than actual yields are expected as crops in the field tend to suffer from environmental stresses that reduce yields. These findings are in agreement with those of Challinor et al. $(2004,2005)$ and Bondeau et al. (2007) who found that crop yield overestimation was a common shortfall of many crop simulation models in Sub-Saharan Africa, because crop models were usually calibrated against data collected in controlled environments, and did not account for nonclimatic factors like pests, weeds and soil-related constraints.

Based on long term simulations, finger millet yields depicted fluctuations across years (Figures 10 and 11) mainly because of fluctuations in rainfall and temperature across the years. Rainfall decrease and temperature increase (T2) had a negative effect on finger millet yields. Abdulhamid (2011), Kurukulasuriya et al. (2006) similarly found that changes in climate directly affected crop yields with declining rainfall resulting in reduced crop yields. Although climate variability has been recorded to account for significant variations in crop yields, there are other reasons which come from agronomic challenges and farmers' management practices, which have been found to affect crop yield production over extended periods of time. These include use of agronomic inputs (Gourdji et al., 2015), disease/pest infestations (Bebber et al., 2013; Timsina and Connor 2001), crop varieties used (Traore at al., 2013), soil management (Rurinda et al., 2013), irrigation (Finger et al., 2011), socio economic conditions (Brown and Funk, 2008; Garrett et al., 2013) political and social strife (Ray, 2012).

Despite this yield decline, there was a significant $(P \leq 0.05)$ difference observed between treatments with highest yields recorded in $\mathrm{TSP}+\mathrm{CAN}$ treatments followed by FYM and control (Figures 10 and 11). The TSP+CAN can thus be seen as a viable method for reducing the effect of climate change on crop yields. Akponikpè et al. (2010) used the APSIM model to carry out a 23-year, long term scenario analysis combining different application rates of cattle manure, millet residue and mineral fertilizer, found 


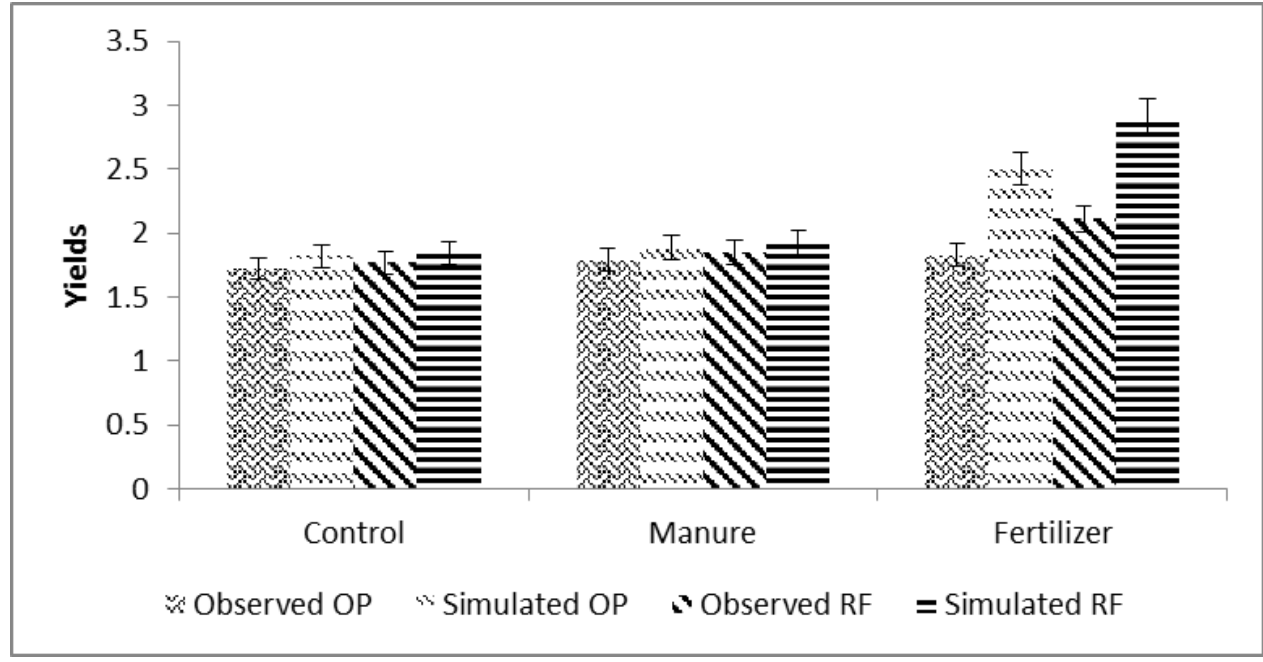

Figure 8. Observed and simulated yields Katangi, Kitui. OP, Oxen plough, RF, Ridges and Furrows. NOTE: Vertical lines on graphs represent error bars.

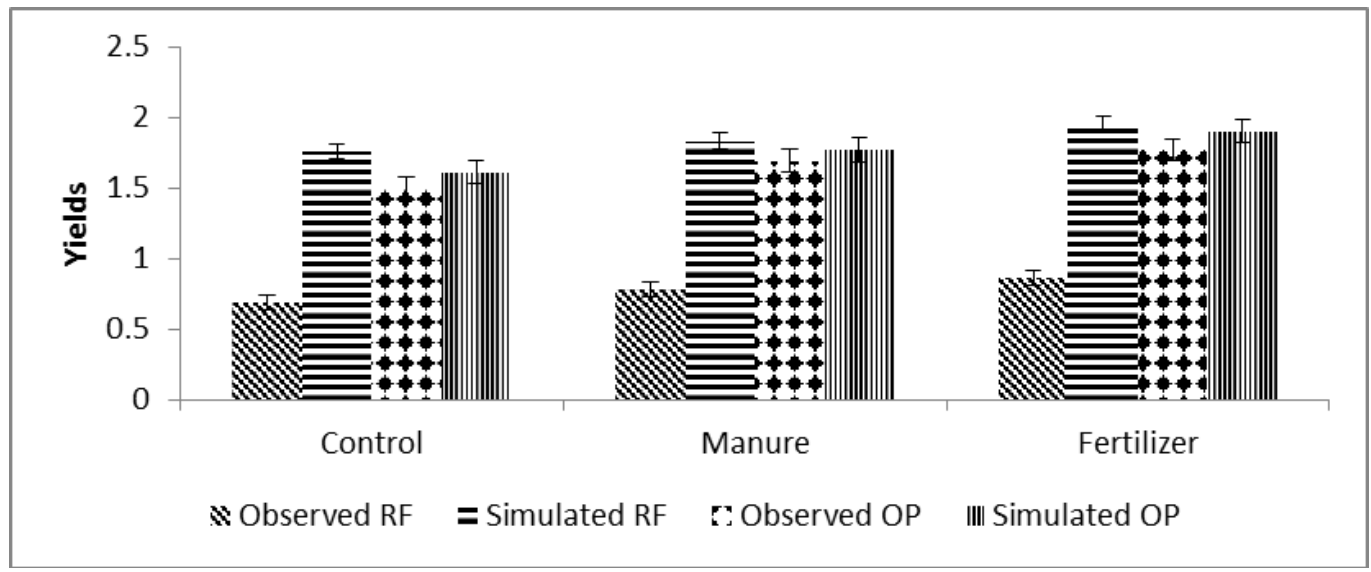

Figure 9. Effect of inputs on observed and simulated yields in Mwala, Machakos. OP, Oxen plough, RF, Ridges and Furrows. NOTE: Vertical lines on graphs represent error bars.

that moderate soil inputs with $\mathrm{N}$ application $\left(15 \mathrm{~kg} \mathrm{~N}^{-1}\right)$ improved both the long term average and the minimum yearly guaranteed yield without increasing inter-annual variability compared to no $\mathrm{N}$ input. Agesa (2014) using the APSIM software to carry out a 50 years long term simulation to determine the effect of soil inputs (FYM, compost and control) on sorghum yields under various cropping systems (monocrop, intercrop and crop rotation) in Yatta sub county found that addition of soil inputs, FYM and composite, provided higher yields when compared to no input treatments.

\section{Effect of climate change on finger millet yields}

The $R 1 \quad(R 0+10 \%$ rainfall) had highest finger millet yields $(\mathrm{t} / \mathrm{ha})$ in both sites with Machakos recording highest yields in TSP+CAN treated plots (2.09 t/ha, $2.11 \mathrm{t} / \mathrm{ha})$ followed by FYM (1.89 t/ha, $2.01 \mathrm{t} / \mathrm{ha})$ and control (1.75 $\mathrm{t} / \mathrm{ha}, 1.96 \mathrm{t} / \mathrm{ha}$ ) in OP and RF respectively (Table 7). A similar trend was observed in Kitui with the $\mathrm{R} 1(\mathrm{R} 0+10 \%$ rainfall) recording highest yields in TSP+CAN treated plots (2.18 t/ha, $2.21 \mathrm{t} / \mathrm{ha}$ ) followed by FYM (2.04 t/ha, $2.01 \mathrm{t} / \mathrm{ha})$ and control (1.85 t/ha, $1.98 \mathrm{t} / \mathrm{ha})$ in $\mathrm{OP}$ and $\mathrm{RF}$ respectively. The T2 $(-10 \%$ rainfall $+20 \mathrm{C})$ had the lowest finger millet yields across sites in the order (for Machakos); TSP+CAN (1.76 t/ha) and FYM (1.63 t/ha) under OP, and control (1.50 t/ha) R2 (R0-10\% rainfall). In RF, lowest yields were recorded in T2 $(-10 \%$ rainfall $+20 \mathrm{C})$ in TSP+CAN (1.44 t/ha) treatments compared to FYM (1.36 $\mathrm{t} / \mathrm{ha}$ ) and control (1.28 t/ha). In Kitui, lowest yields were simulated under T2 $(-10 \%$ rainfall $+20 \mathrm{C})$ TSP+CAN $(1.79$ $\mathrm{t} / \mathrm{ha}, 1.83 \mathrm{t} / \mathrm{ha})$ followed by FYM (1.72 t/ha, $1.61 \mathrm{t} / \mathrm{ha})$ and control (1.53 t/ha, $1.58 \mathrm{t} / \mathrm{ha})$ in OP and $\mathrm{RF}$ respectively 


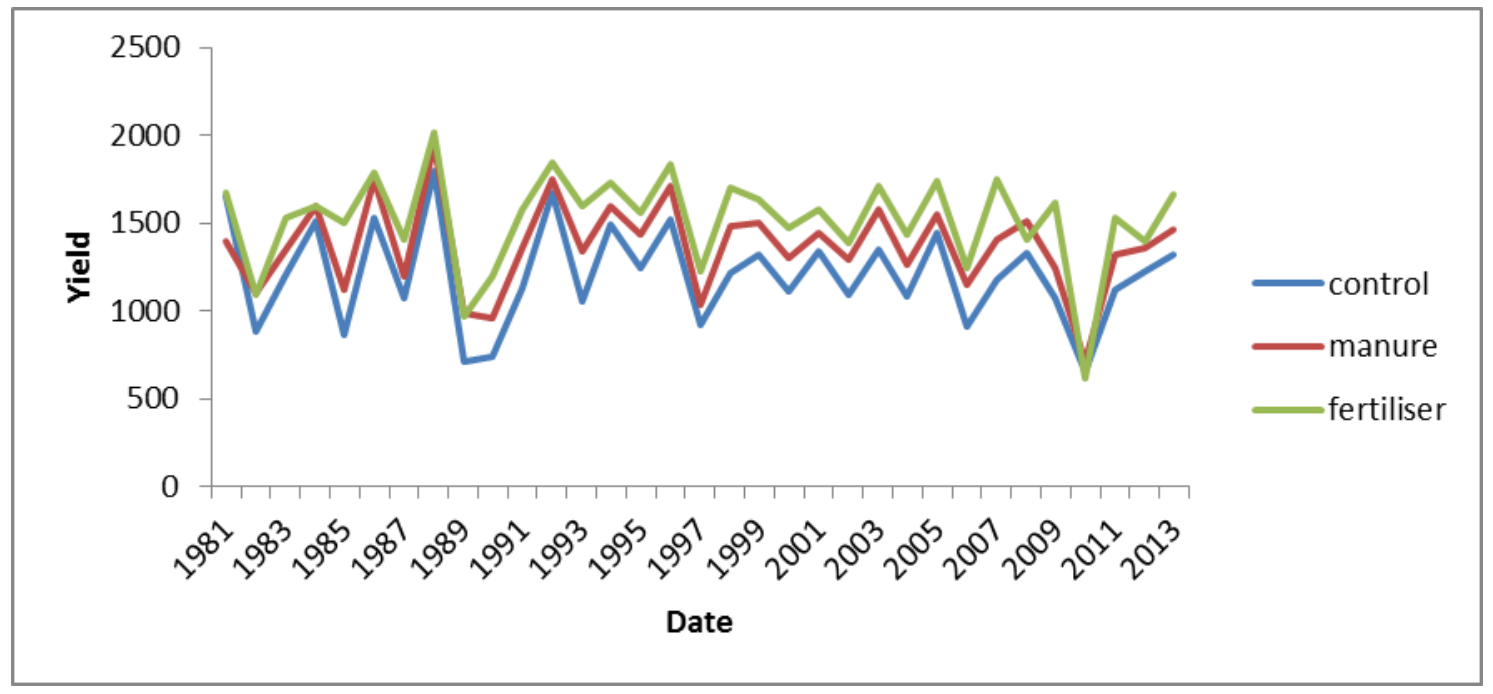

Figure 10. Long term effects of fertilizers on finger millet yields in Katangi, Kitui OP.

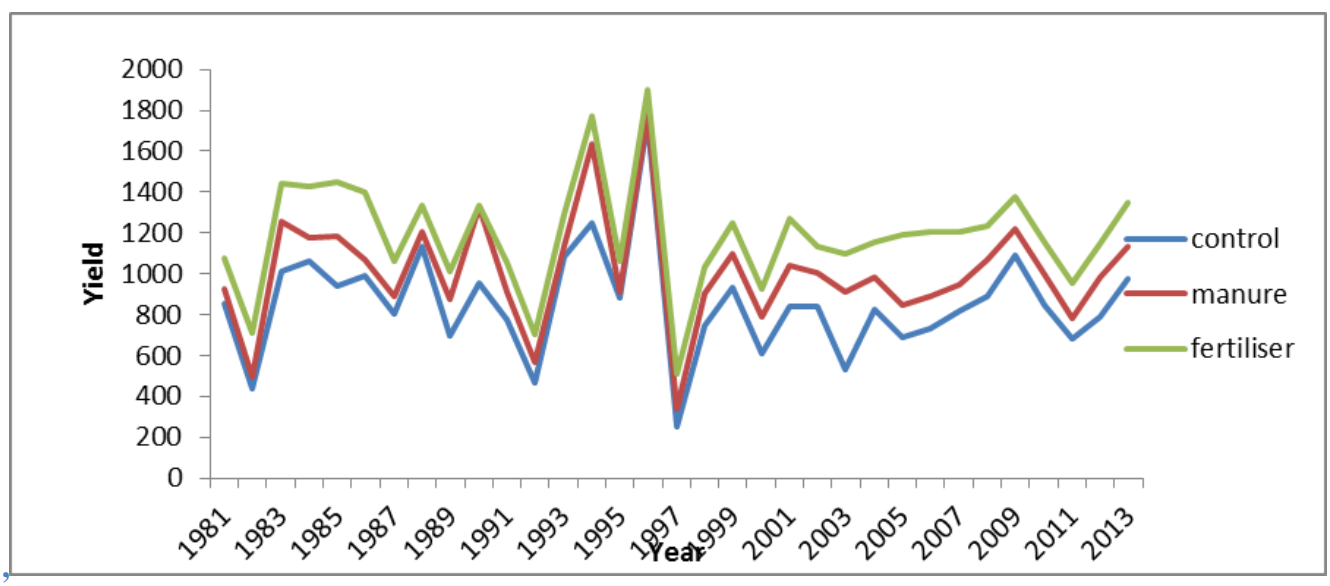

Figure 11. Long term effects of fertilizers on finger millet yields in Mwala, Machakos OP.

(Table 7).

Apart from R1 (R0+10\%), all climate change scenarios [rainfall decrease $\mathrm{R} 2(\mathrm{R} 0-10 \%)$, temperature increase $\mathrm{T} 1$ $(\mathrm{To}+20 \mathrm{C})]$ and their combinations T2 $(-10 \%$ rainfall $+20 \mathrm{C})$ caused a decrease in finger millet yields. The effect of predicted temperature increase (T1) and combined effect of temperature increase and reduced rainfall (T2) had a greater effect on yield than reduced rainfall (Table 7).

Rainfall increase $\mathrm{R} 1$ (+10\% rainfall) caused an upsurge in finger millet yields. This was expected as water is considered one of the main raw materials for photosynthesis, plant growth and subsequently yields production. The results are consistent with those of Basak et al. (2009) and Kang et al. (2009) who found that an increase in rainfall would increase crop yields.

Harvest Choice (2010) similarly reported that more rainfall correlates with higher yield and lower yield variability. The decline in finger millet yields with rainfall reduction may have been due to reduced amounts of available water, leading to reduced plant growth, development and yields. This line of argument is in agreement with Barlow (1986) and Armstrong et al. (1996) who found that reduced soil moisture would reduce crop yields due to reduced leaf expansion, leaf appearance, reduced photosynthesis and grain filling. Mastalerz (1977) similarly found that moisture stress was generally detrimental to plant growth reducing both yield and quality of the crop. Based on APSIM climate simulations, Maccarthy et al. (2013) found that reduced rainfall would reduce crop yields due to diminished crop growth and development. Reduced yields due to increasing temperatures may have been caused by increased rates of metabolic processes, leading to amplified rates of crop maturity, reduced crop development stages and reduced leaf growth. These findings are in tandem with those of Abrol and Ingran (1996) who found that increased tempe- 
Table 7. Effect of climate change on yield in Machakos and Kitui.

\begin{tabular}{|c|c|c|c|c|c|c|c|}
\hline \multirow{3}{*}{\multicolumn{2}{|c|}{ Treatments }} & \multicolumn{6}{|c|}{ Climate Changes } \\
\hline & & \multirow{2}{*}{ Actual } & \multirow{2}{*}{$\begin{array}{l}\text { (To+Ro) } \\
\text { Base line }\end{array}$} & \multirow{2}{*}{$\begin{array}{l}\text { R1 } \\
+10 \%\end{array}$} & \multirow{2}{*}{\begin{tabular}{|c|} 
R2 \\
$-10 \%$ \\
\end{tabular}} & \multirow{2}{*}{$\begin{array}{c}\mathrm{T} 1 \\
+2^{\circ} \mathrm{C}\end{array}$} & \multirow{2}{*}{$\begin{array}{c}\text { T2 } \\
-10 \% ;+2 \circ \mathrm{C}\end{array}$} \\
\hline & & & & & & & \\
\hline \multicolumn{8}{|c|}{ Machakos } \\
\hline & Control & 1.50 & 1.61 & 1.75 & 1.50 & 1.58 & 1.51 \\
\hline \multirow[t]{3}{*}{$\mathrm{OP}$} & FYM & 1.69 & 1.77 & 1.89 & 1.66 & 1.73 & 1.63 \\
\hline & $\mathrm{TSP}+\mathrm{CAN}$ & 1.77 & 1.91 & 2.09 & 1.78 & 1.84 & 1.76 \\
\hline & Control & 0.69 & 1.76 & 1.96 & 1.58 & 1.51 & 1.28 \\
\hline \multirow[t]{2}{*}{$\mathrm{RF}$} & FYM & 0.78 & 1.83 & 2.01 & 1.68 & 1.59 & 1.36 \\
\hline & $\mathrm{TSP}+\mathrm{CAN}$ & 0.86 & 1.95 & 2.11 & 1.71 & 1.65 & 1.44 \\
\hline \multicolumn{8}{|c|}{ Kitui } \\
\hline & Control & 1.72 & 1.82 & 1.85 & 1.69 & 1.61 & 1.53 \\
\hline \multirow[t]{3}{*}{$\mathrm{OP}$} & FYM & 1.79 & 1.89 & 2.04 & 1.75 & 1.64 & 1.72 \\
\hline & $\mathrm{TSP}+\mathrm{CAN}$ & 1.83 & 2.31 & 2.18 & 1.99 & 1.97 & 1.79 \\
\hline & Control & 1.77 & 1.84 & 1.98 & 1.81 & 1.71 & 1.58 \\
\hline \multirow[t]{2}{*}{$\mathrm{RF}$} & FYM & 1.85 & 1.93 & 2.09 & 1.87 & 1.76 & 1.61 \\
\hline & $\mathrm{TSP}+\mathrm{CAN}$ & 2.11 & 2.61 & 2.21 & 2.04 & 1.98 & 1.83 \\
\hline
\end{tabular}

ratures accelerated crop physiological maturity. This in turn shortened crop development stages and reduced harvesting index, crop cycle, rates of photosynthesis and grain filling thus resulting in low crop yields. Brassard and Singh (2008) similarly found that higher temperatures translated into faster crop development and earlier maturation which reduced crop yields as the plant intercepted less cumulative solar radiation before it reached maturity and harvest. Sultan et al. (2013) found that the major effect of climate change on millet and sorghum in West Africa was yield losses induced by higher temperature leading to increased potential evapotranspiration, crop maintenance respiration and a reduction of the crop-cycle length.

A combination of both temperature increase and rainfall decrease T2 $(-10 \%$ rainfall; $+20 \mathrm{C})$ reduced crop yields. This may be attributable to reduced soil water availability for the plant to carry out crucial plant processes such as photosynthesis resulting in the stunting, drying up and eventual death of the crop (Agesa, 2014). Similar results were recorded by Sultan et al. (2012) and Rowhani et al. (2011) who found that with the combination of temperature increase and rainfall decrease, mean crop yields were always found to decrease significantly.

Despite the predicted climate changes causing a decline in crop yields, RF had relatively higher yields than OP across soil fertilizer inputs in both Machakos and Kitui. High crop yields in RF may have been caused by improved soil moisture availability to plants brought about by construction of RF that increased moisture retention for prolonged periods of time. The OP plots having lower yields may have been caused by increased water and nutrient losses through erosion (as discussed under effect of tillage practice and soil fertilizer inputs on observed and simulated finger millet yields).

\section{Conclusion}

The effect of tillage practice varied in the two regions with OP performing relatively better than RF in Machakos and the opposite being true for Kitui. The effect of soil fertilizer inputs had a similar effect on finger millet yields in both regions with the combination of TSP+CAN providing highest yields followed by FYM and control. Simulated yields followed a similar trend with TSP+CAN performing better than the other treatments (FYM and control). However, there was a difference between observed and simulated finger millet yields in Machakos with respect to tillage practices. OP had higher yields than RF in field experiments, while RF performed better than $O P$ in simulations. In comparison, OP had a correlation coefficient (0.5) displaying a moderate relationship between observed and simulated finger millet yields in Machakos. Due to large differences between observed (0.77) and simulated (1.84) values, RF in Machakos was poorly simulated with low correlation coefficient $(0.29)$. For Kitui, yields were moderately predicted and simulated with root mean square errors $(1.04,0.94)$ in $\mathrm{RF}$ and $\mathrm{OP}$ respectively. Apart from $\mathrm{R} 1$ ( $\mathrm{R} 0+10 \%$ rainfall), all climate change scenarios $R 2$ (R0: $-10 \%$ decrease in rainfall), $T 1$ $(\mathrm{TO}+20 \mathrm{C})$ and T2 $(-10 \%$ decrease in rainfall $+20 \mathrm{C}$ increase in rainfall), reduced finger millet yields, with increase in temperature having a higher negative effect 
than decrease in rainfall. Despite the decline in yields, $\mathrm{RF}$ provided higher yields than OP in both regions. The effect of soil fertilizer inputs on different $\mathrm{CC}$ scenarios was similar with TSP+CAN providing higher yields compared to FYM and control.

Both measured and simulated, insitu and across projected CC scenarios, indicated high finger millet yields in RF with application of TSP+CAN. In the absence of inorganic farm inputs, however, use of FYM under RF and OP can be a better alternative. Further studies are nonetheless recommended to generate possible CC adaptation strategies under R2, T1 and T2 in semi-arid regions of Kenya. These strategies should focus on, but not limited to; moisture conservation and breeding of drought tolerant crops.

\section{ACKNOWLEDGEMENT}

RUFORUM is acknowledged for providing funds to undertake this study.

\section{CONFLICT OF INTEREST}

The authors declare that they have no conflict of interest.

\section{REFFERENCES}

Abdulhamid, Y. (2011). The Impact of Climate Change in Nigeria. Computer Engineering and Intelligent Systems, 2(4), 18-25

Abrol, Y. P., \& Ingram, K. T. (1996). Effects of higher day and night temperatures on growth and yields of some crop plants. In: Global climate change and agricultural production. Direct and indirect effects of changing hydrological, pedological and plant physiological processes. Bazzaz, F., Sombroek, W. (eds). Rome: FAO

Adeyemo, A. J., \& Agele, S. O. (2010). Effects of tillage and manure application on soil physicochemical properties and yield of maize grown on a degraded intensively tilled alfisol in southwestern Nigeria. Journal of Soil Science and Environment Management 1(8), 205-216.

Agesa, L. B. (2014). Evaluation of Land Cover and Crop Type Change: Building Evidence On the Effect of Cropping Systems and Organic Inputs On Sorghum Yield and Enhancing Farmers Climate Change Adaptive Capacity. Msc Thesis.

Ahmed, M., \& Hassan, F. U. (2011). APSIM and DSSAT models as decision support tools. 19th International Congress on Modelling and Simulation, Perth, Australia. Pp. 1174-1180. http://mssanz.org.au/modsim2011 accessed on 6/6/2013

Akinyemi, J. O., Akinpelu, O. E., \& Olaleye, A. O. (2003). Performance of cowpea under three tillage systems on an Oxic Paleustalf in southwestern Nigeria. Soil and Tillage Research, 72(1), 75-83.

Akponikpè, P. I., Gérard, B., Michels, K., \& Bielders, C. (2010). Use of the APSIM model in long term simulation to support decision making regarding nitrogen management for pearl millet in the Sahel. European Journal of Agronomy, 32(2), 144154.

Altomore, C., Norvell, W. A., Bjorkman, T., \& Harman, G. E. (1999). Solubilization of phosphates and micronutrients by the plant growth-promoting and biocontrol fungus Trichoderma harzianum Rifai 1295-22. Appl. Environ. Microbiol. 65, 29262933.

Barlow, E. W. R. (1986). Water relations of expanding leaves. Australian Journal of Plant Physiology, 13, 45-58.

Basak, J. K., Ali, M. A., Islam, M. N., \& Alam, M. J. B. (2009, February). Assessment of the effect of climate change on boro rice production in Bangladesh using CERES-Rice model. In Proceedings of the international conference on climate change impacts and adaptation strategies for Bangladesh. Pp. 103-113.

Bebber, D. P., Ramotowski, M. A. T., \& Gurr, S. J. (2013) Crop pests and pathogens move polewards in a warming world. Nat. Climate Change, 3, 985-988.

Bishaw, B., Neufeidt, H., Mowo, J., Abdelkair, A., Muruiki, J., \& Dalle, G., Assefa, T., Guillozet, K., Kassa, H., Dawson, I. K., Luedeling, E., \& Mbow, C. (2013). Famer's strategies for adopting to and mitigating climate variability and change through agroforestry in Ethiopia and Kenya. Orlando, Oregon State University. 95p.

Blake, G. H., \& Hartge, K. H. (1986). Bulk density. In: Klute A. (ed.): Methods of soil analysis. Am. Soc. Agron. 2nd ed. Agron. No. 9(I), 363-375.

Boers, T. M., De, G. M., Feddes, R. A., Ben-Asher, J. (1986). A linear regression model combined with a soil water balance model to design micro-catchments for water harvesting in arid zones. Agric. Water Manage. 11, 187-206.

Bondeau, A., Smith, P. C., Zaehle, S., Schaphoff, S., Lucht, W., Cramer, W., Gerten, D., Lotze-Campen, H., Müller, C., Reichstein, M., \& Smith, B. (2007). Modelling the role of agriculture for the 20th century global terrestrial carbon balance. Global Change Biology, 13(3), 679-706.

Brassard, J. P., \& Singh, B. (2008). Impacts of climate change and $\mathrm{CO} 2$ increase on agricultural production and adaptation options for Southern Québec, Canada. Mitigation and Adaptation Strategies for Global Change 13(3), 241-265.

Bremner, S. M., \& Mulvaney, C. S. (1982). Nitrogen-total. In Methods of Soil Analysis, Part 2, Chemical and Microbiological Properties, 2nd edn (Eds Page A.L, Miller R.H. and Keeney D.R.), Pp. 595-624. Madison, WI: American Society of Agronomy.

Brown, M. E., \& Funk, C. C. (2008). Climate: food security under climate change. Science, 319 (5863), 580-581.

Carberry, P., Hochman, Z., McCown, R., Dalgliesh, N., Foale, M., Poulton, P. (2002). The farmscape appproach to decision support: Farmers, advisrs, researchers monitoring, simulation, communication and performance evaluation. International System for Agricultural Science and Technology, 74, 141-177.

Cater, D. C., \& Miller, S. (1991). Three years' experience with onfarm water catchment water harvesting system in Botswana. Agric. Water Manage. 19, 191-203.

Challinor, A. J., Wheeler, T. R., Craufurd, P. Q., Slingo, J. M., \& Grimes, D. I. F. (2004). Design and optimisation of a large-area process-based model for annual crops. Agricultural and forest meteorology, 124(1), 99-120.

Challinor, A. J., Wheeler, T. R., Slingo, J. M., Craufurd, P. Q., \& Grimes, D. I. F. (2005). Simulation of crop yields using ERA40: limits to skill and nonstationarity in weather-yield relationships. Journal of Applied Meteorology, 44(4), 516-531.

Claassen, M. M. (1996). Effects of Reduced Tillage and Crop Rotation on Wheat and Grain Sorghum. In the Field Research Progress report No. 762. Kansas Agricultural Experiment Station: Manhattan, KS. Pp. 26-29.

Cresswell, H. P., Hume, I. H., Wang, E., Nordblom, T. L., 
Finlayson, J. D., \& Glover, M. (2009). Catchment response to farm scale land use change. CSIRO and NSW Department of Industry and Investment. www.clw.csiro.au/publications/science/2009/saf-catchmentresponse-farm-scale-land-change.pdf (accessed 15 May 2013).

Crown, T. W, Dunn, R. A. (2010). Soil organic matter, green manures and cover crops for nematode Management. Gainsville,University of Florida.

Dalgliesh, N. P., \& Foale, M. A. (2005). Soil matters: Monitoring soil water and nutrients in dryland farming. Agric. Production Systems Res. Unit, Toowoomba, Australia.

van Loon, A., Droogers, P. (2006). Water Evaluation and Planning System, Kitui-Kenya. Wageningen: WatManSup Research. 69p.

Estefan G., Sommer R., \& Ryan T. (2013). Methods of Soil, Plant and Water Analysis. ICARDA (International Center for Agricultural Research in the Dry Areas), Beirut.

FAO. (2008). Climate Change, energy and food. Rome, FAO.

Finger, R, Hediger, W. \& Schmid, S. (2011). Irrigation as adaptation strategy to climate change - a biophysical and economic appraisal for Swiss maize production. Climatic Change, 105, 509-528.

Flato, G. M., \& Boer, G. J. (2001), Warming asymmetry in climate change simulations, Geophysical Research Letters, 28,195198.

Flato, G. M., Boer, G. J., Lee, W. G., McFarlane, N. A., Ramsden, D., Reader, M. C., \& Weaver, A. J., (2000). The Canadian Centre for Climate Modelling and Analysis global coupled model and its climate, Climate Dynamics, 16, 451-467.

Fox, P., \& Rockstrom, J. (2003). Supplemental irrigation for dryspell mitigation of rainfed agriculture in the Sahel. Agricultural water management, 61(1), 29-50.

Garrett, R. D, Lambin, E. F, \& Naylor, R. L. (2013) Land institutions and supply chain configurations as determinants of soyabean planted area and yields in Brazil. Land Use Policy, 31, 385-396.

Gee, G. W., \& Bauder, J. W. (1986). Particle-size analysis. In A. Klute (ed.) Methods of soil analysis. Part 1. Physical and mineralogical methods. 2nd ed. Agron. 9, 383-411

Gourdji, S. M, Sibley, A. M., \& Lobell, D. B. (2013) Global crop exposure to critical high temperatures in the reproductive period: historical trends and future projections. Environ. Res. Lett., 8, 24-41.

Government of Kenya (GoK). (2011). National food and nutrition security policy. Nairobi.

Hansen, B., Schjonning. P., Sibbesen, E. (1999). Roughness indices for estimation of depression water storage capacity of cultivated soil surfaces. Soil and Tillage Research, 53, 103111.

Harvest Choice (2010) Assessing the Impact of Rainfall Variability on Maize Yield Potential in Sub-Saharan Africa. Accessed from http://harvestchoice.org/labs/rainfall-variabilityand-crop-yield-potential. Accessed on 2/2/2017.

Intergovernmental Panel Climate Change (IPCC) (2007). Climate Change: Impacts, Adaptation and Vulnerability: Contribution of Working Group II to the Fourth Assessment Report of the Intergovernmental Panel on Climate Change. Cambridge University Press, Cambridge, U.K. and New York, NY.

Jaetzold, R., Schmidt, H., Hornetz, B., Shisanya, C. (2006). Farm management hardbook of Kenya.Natural conditions and farm information, vol. II, Part C1 - East Keny, 2nd edition. Ministry of Agriculture, Kenya.

Jensen, J. R., Bernhard, R. H., Hansen, S., McDonagh, J.,
MØberg, J. P., Nielsen, N. E., \& Nordbo, E. (2003). Productivity in maize based cropping systems under various soil-waternutrient management strategies in semi-arid Alfisol environment in East Africa. Agric. Water Management, 59, 217-237.

Jewell, D. C., Weddington, S. R., Ransom, J. K., \& Pixley, K. V. (1995). Maize Research for Stress Environments. Proceedings of the fourth Eastern and Southern Africa. Regional maize conference held at Harare, Zimbabwe. 28th March to 1st April, Mexico D.F CIMMYT, p. 306.

Jia, Y, Li, F. M, Wang, X, L, \& Yang, S. M. (2006). Soil water and alfalfa yields as affected by alternating ridgs and furrows in rainfall harvest in a semi-arid environment. Field crop research, 976, 167-175.

Jones, J. W. (2003). Agricultural responses to climate variability and climate change. Paper presented at Climate Adaptation.net Conference Insights and Tools for Adaptation: Learning from Climate Variability, 18-20 November, Washington, DC. July 1994. Gaborone, Botswana.

Kang, M. S., Koo, J. H., Chun, J. A., Her, Y. G., Park, J. W., Yoo, K. (2009). Design of drainage culverts considering critical storm duration. Biosystems Engineering 104, 425-434.

Kaumbutho, P. G., \& Simalenga, T. E. (1999). Conservation tillage with animal traction. A resource book of the Animal Traction Network for Eastern and Southern Africa (ATNESA). Harare: Zimbabwe.

Kaumbutho, P., \& Kienzle, J. (2007). Conservation agriculture as practised in Kenya: two case studies. Nairobi, Kenya: African Conservation Tillage Network (ACT); Centre de Coopération Internationale de Recherche Agronomique pour le Développement (CIRAD); Food and Agriculture Organization of the United Nations (FAO).

Keating, B. A., Carberry, P. S, Hammer, G. L., Probert, M. E., Robertson, M. J., Holzworth, D., Huth, N. I., Hargreaves, J. N. G., Meinke, H., Hochman, Z., McLean, G., Verburg, K., Snow, V., Dimes, J. P., Silburn, M., Wang, E., Brown, S., Bristow, K. L., Asseng, S., Chapman, S., McCown, R. L., Freebairn, D. M., Smith, C. J. (2003). An overview of APSIM, a model designed for farming systems simulation. European Journal of Agronomy, 18, 267-288.

Kotschi J. (2006). Coping with Climate Change, and the Role of Agrobiodiversity. Conference on International Agricultural Research for Development. Tropentag University of Bonn. October 11-13, 2006.

Kurukulasuriya, P. R., Mendelsohn, R., Hassan, J., Benhin, M., Diop, H. M., Eid, K. Y., Fosu, G., Gbetibouo, S., Jain, A., Mahamadou, S., El-Marsafawy, S., Ouda, M., Ouedraogo, I., Sène, D., Maddision, N., Seo Dinar, A. (2006). Will African Agriculture Survive Climate Change? World Bank Economic Review, 20(3), 367-388.

Lema, A, Degebassa, A. (2013). Comparison of chemical fertilizer, fish offal's fertilizer and manure applied to tomato and onion. African Journal of Agricultural Research, 8(3), 274-278.

Lipper, L., Neves, B., Wilkes, A., Tennigkeit, T., Gerber, P., Henderson, B., Branca, G., \& Mann, W. (2011). Climate change mitigation finance for smallholder agriculture. In: A guide book to harvesting soil carbon sequestration benefits. Food and Agriculture Organization of the United Nations (FAO) report. FAO, Rome.

MacCarthy, D. S., Diancoumba, M., Freduah, B. S., Adiku, S. G. K., Agali, A., Hathie, I., Lizaso, J., Fatondji, D., Adams, M. Tigana, L., Koomson, E., Traore, P. C. S., Traore, S., Amikuzuno, J., Naab, J. B., Diarra, B., Sarr, D. Z., N'diaye, O., Sanon, M. (2013). An Integrated Assessment of Climate 
Change Impact on Crop Production in the Nioro du Rip Basin of Senegal I: Crop Modelling Presented at AGMIP 4TH ANNUAL GLOBAL WORKSHOPColumbia University New York New York 10/28/2013 - 10/30/2013.

Madegwa, Y., Onwonga, R., Shibairo, S., Karuku, G. (2016) Farmer Perception and Adaptation Strategies on Climate Change in Lower Eastern Kenya: A Case of Finger Millet. Journal of Agricultural Science, 8(12), 33-40.

Magdoff. F., \& Weil, R. (2004). Significance of soil organic matter to soil quality and health. In Oades F., \& Weil, R. (eds). Soil Organic Matter in Sustainable Agriculture. Boca Raton: CRC Press.

Magunda, M. K., \& Tenywa, M. M. (1999). Soil and water conservation. Kampala. National Agricultural Research Organization (NARO).

Mastalerz, J. W. (1977). The Greenhouse Environment. John Wiley and Sons. p. 629.

McLean, E. O, Heddleson, M. R., Post, G. J. (1959) Aluminium in soils. III A. Comparison of extraction methods in soils and clays. Soil Sci. Soc. Am. Proc., 23, 289-293.

Miriti, J. M., Kironchi, G., Esilaba, A. O., Gachene, C. K. K., Heng, L. K., \& Mwangi, D. M. (2013). The effects of tillage systems on soil physical properties and water conservation 28 in a sandy loam soil in Eastern Kenya. Journal of Soil Science and Environmental Management, 4(7), 146-154.

Miriti, J. M., Kironchi, G., Esilabac, A. O., Heng, L. K., Gachene, C. K. K., \& Mwangi, D. M. (2012). Yield and water use efficiencies of maize and cowpea as affected by tillage and cropping systems in semi-arid Eastern Kenya. Agricultural Water Management, 115, 148-155.

Moore, D. S., \& McCabe, G. P. (1993). Introduction to practice of statistics, second edition. Freeman, New York, p. 854.

Morris, M. (2006). Soil Moisture Monitoring: In Low-Cost Tools and Methods Montana: NCAT

Nelson, D. W., \& Sommers, L. E. (1982). Total Carbon, organic carbon and organic matter Methods of soil analysis edition Part 2. ASA, 9, 2nd Edition.

Ngeve, J. M. (2003). Cassava root yields and culinary qualities as affected by harvest age and test environment. Journal of the Science of Food and Agriculture, 83(4) ,249-257.

Obilana, A. B, (2003). Overview: importance of millets in Africa. In: Belton, P. S., Taylor, J. P. N. (Eds). Afripro, Workshop on the proteins of sorghum and millets: Enhancing nutritional and functional properties for Africa. Pretoria, South Africa, 2-4 April 2003.

Oduori, C. O. A. (2008). Breeding investigations of finger millet characteristics including blast disease and striga resistance in western Kenya. PhD dissertation. University of KwaZulu-Natal Republic of South Africa Available online: http://hdl.handle.net/10413/74 Accessed: May 122012.

Okalebo, J. R., Gathua, K. W., Woomer, P. L. (2002). Laboratory methods of soil and plant analysis: A working manual. 2nd ed. TSBF-CIAT and SACRED Africa, Nairobi

Okalebo, J. R., Njuho, P. M., Gathua, K. W. (1990). Effect of form and method of phosphate fertilizer application on maize sorghum and millet growth semi-arid environment of Kenya. II: Effect on Bulrush and finger millet. E. Afr. For J., 55(4), 239248.

Olsen, M. R., \& Sommers, L. E. (1982). Phosphorus pp. 403-427 in Buxton, ed., Methods of Soil Anaysis: Chemical and micro biological properties 2nd ed., Madison: Soil Science Society of America.

Pauw, W. P., Mutiso, S., Mutiso, G., Manzi, H. K., Lasage, R., Aerts, J. C. J. H. (2008). An Assessment of the Social and
Economic Effects of the Kitui Sand Dams Community based Adaptation to Climate Change Nairobi: SASOL \& Institute for Environmental Studies. Pp. 1-64.

Probert, M. E., Dimes, J. P., Keating, B. A., Dalal, R. C., \& Strong, W. M. (1998). APSIM's water and nitrogen modules and simulation of the dynamics of water and nitrogen in fallow systems. Agric. Syst., 56, 1-28.

Ray, S. (2012). Political Economy of Africa, University of Rochester.

Reilly, J. M. (2001). Agriculture: the potential consequences of climate variability and change for the United States Cambridge University Press, Cambridge, 2002, 136p.

Richards, L. A. (1948). Porous plate apparatus for measuring moisture retention and transmission by soil. Soil Sci., 66,105110.

Rowhani, P., Lobell, D. B., Linderman, M., Ramankutty, N. (2011). Climate variability and crop production in Tanzania. Agricultural and Forest Meteorology, 151:449-460.

Rurinda, J., Mapfumo, P., van Wijk, M. T., Mtambanengwe, F., Rufino, M. C., Chikowo, R., \& Giller, K. E. (2013). Managing soil fertility to adapt to rainfall variability in smallholder cropping systems in Zimbabwe. Field Crops Research, 154, 211-225.

Samantha, J. (2001). Sustainability and institutional perspectives on natural resource planning and management at the Ukwimi resettlement scheme, Zambia. Third World Planning Review, 23(4), 431-450.

Smith, J., Smith, P., \& Addiscott, T. (1996). Quantitative methods to evaluate and compare soil organic matter (SOM) models. In Evaluation of soil organic matter models. Springer, Berlin, Heidelberg. Pp. 181-199.

Sultan B, Roudier P, Quirion P, Alhassane A, Muller B, Dingkuhn M, Ciais P, Guimberteau M, Traore, S., Baron, C. (2013). Assessing climate change impacts on sorghum and millet yields in the Sudanian and Sahelian savannas of West Africa. Environ. Res. Lett., 8, 1-9.

Taylor, J. R. N. (2003). Overview: Importance of sorghum in Africa. In Afripro: Workshop on the Proteins of Sorghum and Millets: Enhancing Nutritional and Functional Properties for Africa, Pretoria, 2(4).

Thiongo, K., Ngaira, J. K. W., China, S. (2016). Strategies used by farmers to cope with drought in Machakos County, Kenya. Journal of Applied Management Science. 2(6), 1-10.

Timsina, J., \& Connor, D. J. (2001). Productivity and management of rice-wheat cropping systems: issues and challenges. Field Crops Res., 69, 93-132.

Tolessa, D. (2006). Effect of tillage system, residue management and nitrogen fertilization on maize production in western Ethiopia. Ph. D. thesis, University of the Free State, Bloemfontein.

Traore, B., Corbeels, M., van Wijk, M. T., Rufino, M. C., \& Giller, K. E. (2013). Effects of climate variability and climate change on crop production in southern Mali. Eur. J. Agronomy, 49, $115-125$

Tsubo, M., Walker, S., \& Ogindo, H.O., (2005). A simulation model of cereal-legume intercropping systems for semi-arid regions. Model development. Field Crops Res., 93, 10-12.

Uloro, Y. A., \& Gebrekidan, H, (2002). Soil and water conservation (tied ridges and planting methods) on cultivated lands: The case of eastern Ethiopian: Soil and Water Management Research Program, Alemaya University.

Wagate, C. G., Mbaria, J. M., Gakuya, D. W., Nanyingi, M. O., Kareru, P. G., Njuguna, A., Gitahi, N., Macharia, J. K., \& Njonge, F. K. (2010). Screening of some Kenyan medicinal plants for antibacterial activity. Phytotherapy research, 24(1), 
150-153.

Wang, E., Yu, Q., Wu, D., Xia, J. (2008). Climate, agricultural production and hydrological balance in the North China Plain. International Journal of Climatolology, 10, 1002-1677.

Whisler, F. D., Acock, B., Baker, D. N., Fye, R. E., Hodges, H. F., Lambert, J. R., Lemmon, H. E., McKinion, J. M., Reddy, V. R. (1986). Crop simulation models in agronomic systems. Advances in Agronomy 40, 141-208.

Willmott, C., \& Matsuura, K. (2005): Advantages of the Mean Absolute Error (MAE) over the Root Mean Square Error (RMSE) in assessing average model performance, Clim. Res., 30, 79-82.
World reference base for soil resources (WRB). (2006). A framework for international classification, correlation and communication. FAO, Rome.

Wu, D., Yu, Q., Lu, C., Hengsdijk, H. (2006). Quantifying production potentials of winter wheat in the North China Plain. European Journal of Agronomy 24, 226-235.

Xu, G., Chen, T., Liu, X., Jin, L, Wang, W. (2011). Summer temperature variations recorded in tree-ring $\delta 13 \mathrm{C}$ values on the northeastern Tibetan Plateau. Theoretical and Applied Climatology 105(1-2), 51-63. 